\title{
Indicators to prevent university drop-out and delayed graduation. An Italian case
}

\begin{tabular}{|r|l|}
\hline Journal: & Journal of Applied Research in Higher Education \\
\hline Manuscript ID & JARHE-10-2018-0201.R2 \\
\hline Manuscript Type: & Research Paper \\
\hline Keywords: & $\begin{array}{l}\text { Undergraduate, drop-out, delayed graduation, student satisfaction, } \\
\text { teaching and research quality, commuter and residential students }\end{array}$ \\
\hline \multicolumn{2}{|l}{} \\
\hline
\end{tabular}

\section{SCHOLARONE \\ Manuscripts}


Indicators to prevent university drop-out and delayed graduation. An Italian case

\begin{abstract}
Purpose: Research on the association between individual characteristics of undergraduate students, drop-out and delayed graduation is still evolving. Therefore, further evidence is required.

Design/methodology/approach: This paper reports on an empirical study examining the relationship between students' individual characteristics and delayed graduation. The analysis is based on a sample of 1167 students who have registered on and have completed a full-time undergraduate program in Italy. Using a Probit model, the findings document the individual, background and environmental indicators that play a role in explaining delayed graduation.
\end{abstract}

Findings: The study observes that students who commute to university perform better than those residing on campus. Other factors increasing the probability of completing the undergraduate programme on time include individual characteristics (e.g. gender and age), student background (family income, education), institutional environment (teaching and research quality) and student satisfaction. Finally, some policy implications are discussed.

Social implications: A direct policy implication of these findings is that supporting academic staff in order to enhance their performance in both research and teaching has a positive effect on the performance of the students.

Originality/value: This paper contributes to the debate on the impact of institutional quality on students' performance, aiming to address the question of balance between teaching and research orientation.

Keywords: Undergraduate; drop-out; delayed graduation; student satisfaction; teaching and research quality. 


\section{Introduction}

The Lisbon Strategy (March 2000), the Bologna process (Eurydice, 2010) and the training priorities provided by Europe 2020 (EU2020) are committed to the establishment of a knowledge economy that promotes employability and the development of human capital via lifelong learning and social equity (EC, 2009; Dion, 2005).

One of EU2020's top priorities is to see an expansion of education at all levels throughout Europe, with two specific goals: to reduce school drop-out by $10 \%$ and to increase the number of adults between the ages of 30 and 34 in higher education by $40 \%$. These are no trivial goals for Italy given the declining numbers of students enrolling onto undergraduate programmes and the increasingly long time it takes for them to complete their degrees. According to Eurostat (2014), Italy ranks towards the lower end of the spectrum in respect of its graduate numbers, followed only by the Czech Republic, Romania, and Slovakia. Among the 25-34 age group, only 19\% of the Italian population have obtained a bachelor's degree, compared to a European average of around $30 \%$.

According to Schnepf (2015), Italy has the highest drop-out out rate out of 15 European countries. Furthermore, the Italian student's decision to drop-out is permanent, in comparison with their European peers, who decide to return and complete their degree later in life.

In Italy, non-completion of degrees affects $40 \%$ of enrolled students, whilst in other Western European countries the figure varies between 21\% and 28\% (Quinn, 2013).

D'Hombres (2007) asserts the importance of studying the Italian case, which is characterised by high rates of university drop-out out and low graduation rates. These are important indicators of the inefficiency of the tertiary education system.

Therefore, it seems relevant to focus on the situation in Italy in order to understand which factors influence student academic behaviour and progression. Student drop-out and delayed graduation have been recognised as two important issues in higher education institutions in many European 


\section{Literature Review}

Student performance has been studied from a range of economic, psychological, and sociological perspectives in order to understand which factors affect behaviour and decision-making. Educators, academics, and policy makers have linked student performance to factors relevant to these perspectives along with the quality of higher education and the suitability of institutions for individual students (Leveson et al, 2013; Zotti, 2015; Bowles and Brindle, 2017).

In general, two main lines of research can be distinguished. The first refers to the analysis of the role played by the "macro-categories", such as the socio-educational background of the student. The second strand of research focuses on the impact of "micro-categories" on student performance. Regarding the first research area, relevant studies have identified the influence of social indicators including gender, socio-economic status, family background and ethnic group (Aikens and Barbarin 2008; Thiele et al., 2016; Ghignoni (2017). In the Italian context, Cingano and Cipollone (2007) have used national institutional data (ISTAT: Italian National Institute of Statistics) to highlight the importance of socio-familial backgrounds of students. For example, the probability of university drop-out decreases in relation to the number of years the father spends in education. This aspect emphasises the impact of parental educational background on the academic performance of their offspring. Other important determinants for student drop-out include student educational background, academic degree performance, and personal characteristics such as gender and place of residence. In this regard, Belloc et al. (2011) have showed that high drop-out probability is linked to secondary school final marks and low 
individual students' performance. Boero et al. (2005) has adopted a probit model (also used in the present research) to evaluate the impact of the Italian academic reform (2001) on students' withdrawal and progression and has demonstrated that the type of high school chosen by students and their final grade have a statistically significant effect on the probability of drop-out. Using data from the five waves of the Italian Longitudinal Household Survey, through the analysis of cross-tabulation and multinomial logistic regression models, Triventi and Trivellato (2009) found that the percentage of drop-outs is higher among high-intensity workers compared to full-time students and low-intensity workers. Italian students from upper middle classes are less likely to retire or graduate late than students in lower middle classes.

Regarding the second line of research, several studies have considered the effects of students' personal characteristics, the role of internal and external motivation, student attitude to academic study and any related employment or professional goals (Mega et al., 2014; Richardson et al., 2012).

Belloc et al. (2010) have used university administrative data to provide information on student performance. The authors do not consider the drop-out phenomenon as a binary choice set (yes or no) but offer realistic treatment of withdrawal decisions analysing several outcomes: drop-out of university, retention in the same faculty, change of faculty, change of institution. This method enables to obtain more detailed information on the type of drop-out/withdrawal and on the motivations relating to it.

Furthermore, students with lower grades and incomes of up to $10,000 €$ per year are less likely to drop-out. This can be explained by the family and financial pressures placed upon this group to conclude their studies as soon as possible. Adult students also have a lower likelihood of dropout. This could be explained by the fact that adults, and potentially workers, are more motivated to conclude their training path in time.

In respect to the ongoing debate on student performance in higher education two issues are 
highlighted as worthy of further exploration: the difference in performance between students who reside on campus and those who commute to campus, and the role played by the institutional environment (including teaching and research quality).

With regards to the first issue, comparisons between commuter and residential students have been analysed over the last four decades following the work of Chickering (1974). According to Horn and Berktold (1998) and Snyder and Dillow (2011), the majority of college students commute to campus in US. However, Jacoby (2000) found that these students were highly likely to be less involved in academic pursuits than residential students due to multiple time constraints. This could be problematic because academic engagement, e.g. interacting with academic staff and other students, has been shown to add value to the student experience (Chickering, 1974; Kuh et al., 2011; Newbold et al., 2011). However, Alfano and Eduljee (2007) who performed a survey analysis to investigate the relationship between the number of hours worked and GPA among residential and commuter students, found no statistically significant relationship. This broader comparative literature presents a plethora of research contributions involving samples of differing sizes weighted more towards students residing on campus (Dugan et al., 2008; Weissberg et al., 2003).

Understanding the difference in performance between commuter and residential students is a significant step towards identifying student groups most at risk of delayed graduation. In Italy, the aspiration of the higher education system is to increase the number of students with a degree, in line with other European countries. Within this context, it is important to study the progression of residential and commuter students to help identify and support the student group most at risk. With regards to the issue of institutional environment, research and teaching quality have already been explored in previous studies.

If the positive effects of teaching quality are well known in literature, the analysis of teachers' research performance on students' careers has not received the same attention. As pointed out by 
several scholars, research drives good teaching. Current research has focused on how the relationship between research and teaching could or should work (Malcolm, 2014; Jung and Kim, 2017).

Raponi et al. (2016) have analysed university performance with a multifactorial approach, adopting a multivariate technique (biclustering) to compare private and public universities in Italy. They have focused on different dimensions such as productivity, teaching, research and internationalisation, comparing 55 Italian Economics faculties and identifying differences between public and private universities. The study showed that private institutions present better performances compared to public universities, especially in terms of productivity and internationalisation. In addition, private professionals are very active on fund-raising and are more careful about providing human and structural services to students. Public universities are active in the internationalisation of education (incoming and outgoing students) and in implementing actions aimed at supporting students during their course of study.

Based on these findings, it would make sense to allocate increased resources to research projects rather than teaching programmes. However, the existence of a direct connection between research and teaching activity is not obvious (Gibbs, 1995). For example, in their meta-analysis Hattie and Marsh (1996) conclude that there is not a strong relationship between research and teaching performance.

Furthermore, the teaching and research dimensions are not easy to analyse as they are influenced by a number of external variables such as personal motivation and interests, time commitments and orientations to teaching (Robertson and Bond, 2001). A review of the literature has demonstrated two opposing positions. The first is that the relationship between teachers' research productivity and teaching efficacy is very low (Noser et al., 1996; Coate et al., 2001; Pocklington and Tupper, 2002). The second is that research carried out by teachers has a positive impact on students' learning (Scott, 2002; Healey and Roberts, 2004). Healey (2005) in particular showed 
there are positive benefits for undergraduate students' learning when their teachers are actively involved in research.

The incentives offered to those focusing on either teaching or research in Italy could contribute to a shift in the equilibrium. Young (2006) found that academic teachers perceived teaching as a highly demanding career with a low return in terms of salary and social status in comparison to research and other institutional activities. This aspect has been recognised to drive academics to give much more emphasis to their research as it repays more than teaching activities (Taylor et al., 2008). These aspects can lead to a situation in which an institution "specialises" in only one dimension. Analysing the impact of the two activities is a fundamental step in adopting the most appropriate approach both at institutional and national level. A number of authors have stressed the role played by the model organization and college mission on students' results and wellbeing (Thiele et al., 2016; Choi and Rhee, 2014).

\section{Paper aims and literature contribution}

This paper contributes to the debate about the impact of institutional quality on the performance of residential and commuter students, aiming to address the question of balance between teaching and research orientation.

In contrast to previous important research that utilised national data banks (Cingano and Cipollone, 2007; Triventi and Trivellato, 2009), this study includes individual characteristics collected from the administrative offices of universities - which may be potentially relevant to understand drop-out probability.

Furthermore, the paper tries to address another relevant issue that is common to many universities and other higher education institutions: the difference in performance between residential and commuter students.

The research goal is to elucidate two issues that, as far as the authors know, have not been fully 
explored yet. Firstly, it focuses on the impact of departments' features on students' performance. Although it has been demonstrated that teaching quality performance reduces students' propensity to drop-out (Kemran, 2016; Johnes and Mcnabb, 2004; Hanushek and Rivkin 2006), the understanding of the effects of research quality and productivity on students' performance appears to be limited. This analysis aims to fit into the current debate by testing the impact of research quality - measured by national indicators provided by the Italian Ministry of Education, University and Research (MIUR) - and teaching quality - proxied by students' satisfaction - on students' careers. Secondly, the research compares the performance of two groups of students: residential and commuter students (Jacoby, 2000). This research question is important because the two groups present very different needs and behaviours. For instance, one can think how their status affects the demand of services both in terms of quantity and typology (student accommodation, transports, public areas, etc.) (Bowles and Brindle, 2017).

Studies on microdata by Belloc et al. (2011); and Burgalassi et al. (2018), analyse cohorts of students from the same Italian university; however, unlike the present study, which involves all the subject areas present, they focus on singular specific departments (economics in the first case and education sciences in the second case).

In considering the impact of two relevant variables in the explanation of drop-out - teaching and research quality - neither of these studies focus on comparing the performance between residential and commuter studies as the present study does. In addition, both studies analyse data from the same large University in Rome: "Sapienza". In the present case, a medium-size and insular University, the University of Sassari (see Context analysis section) has been considered. Raponi et al., 2018 analyse the data of 55 Italian Universities but they have only included data from economics faculties in their sample. Moreover, they have not focused on the comparison between residential and commuter students. Finally, they adopted different indicators to analyse the variables of teaching and research. For example, they have not considered student 
satisfaction and the ANVUR (National Agency for the Evaluation of the University System and Research) index.

To close this gap, information about students registered in the Autumn 2008 cohort at the University of Sassari was scrutinised in the present research. The implementation of a longitudinal analysis solves any problems of data comparability over time. In fact, all students faced the same environment at the same time, which helped to model and interpret the variables under study. Firstly, the University of Sassari is a good Italian case study as it is representative of the national situation (60\% delayed graduation) (Zotti, 2015). Secondly, in the Italian context the University of Sassari is a medium-sized institution (12,000 students in 2014/2015) and a medium-ranked university. Therefore, results could be generalized to similar institutions within the Italian system.

Thirdly, the isolated condition of Sardinia dramatically reduces the outflow/inflow of students. This aspect leads to a high homogeneity among the student population. Although at first glance this seems to constitute a problem, it is advantageous for the research. The limited presence of ethnic and cultural diversity makes the pattern clearer. There are no interaction issues between our variables of interest through belonging to minority groups, avoiding possible sample and estimator biases. It is observed that residential students perform worse than commuter students defined as all students who do not live in institution-owned housing on campus. Furthermore, other factors seem to explain the success in attending an academic institution, measured here as the probability to finish the undergraduate programme within the nominal duration. These include individual characteristics (e.g. gender and age), students' background (family income, secondary schools, and final marks obtained), institutions' environment (departments' teaching and research quality) and student well-being (student satisfaction). Finally, some policy implications are discussed.

Dealing with residential and commuter students one can notice that the analyses are mostly 
based on aggregated unbalanced data in which residential institutions are often over-represented (Gianoutsos, 2011). In order to better compare the two statuses across the student population, it is necessary to analyse micro-data and use a balanced sample. The data in this study satisfies both these requirements. The sample contains micro-information of a sufficiently balanced number of commuter and residential students, 341 and 826 respectively. This allows to correctly identify and measure the impact of this status on student performance. As it will be discussed later, some policy implications could be derived from this study.

\section{Background information and data}

\subsubsection{The Italian university reform}

The current regulatory framework for the tertiary education system in Italy is the product of various reforms introduced after the post-war period and aimed at extending access to university education until the 1980s. Since 1999, the Italian academic system has been completely reformed to achieve the objectives of the Bologna Declaration. The old systems envisaged four/five-years degree programmes. The new one, introduced with the reform enacted by the MIUR decree No. 509 of 1999 (which came into effect in 2001) and completed by MIUR decree No. 270 of 2004, provides 2 main cycles. The first cycle, Laurea degree, is a three-year full-time programme with a workload of 180 ECTS credits, corresponding to the bachelor degree of the Bologna Declaration. The second cycle consists of a further two-year full-time programme to obtain 120 ECTS credits and to achieve Laurea magistrale, corresponding to the master-level degree of the Bologna Declaration. This cycle of education is supposed to prepare students for higher, managerial and professional positions (EC, 2010).

According to Ghignoni (2017), the reform aimed to increase the number of graduate students, particularly by encouraging demotivated students to obtain at least a first-level degree, and to reduce the number of years required to complete a degree. 
Through analysis of the academic careers of students during the pre-reform (1995 and 1998) and post-reform (2001) periods Di Pietro and Cutillo (2008), have evinced that the reform has contributed to changing students behaviour, reducing their probability to drop-out.

Ghignoni (2017) used a bivariate probit model and sample decomposition techniques to analyse determinants of the reduction in the drop-out rate in the Italian university system during the economic crisis. He discovered that the current drop in enrolment in Italian universities is mainly due to a differentiation in the behaviour of the middle class and the bourgeoisie. The cultural background of families maintains its influence on enrolment, but loses ground in preventing abandonment.

During the economic crisis, the drop-out probability of students coming from the middle classes has increased, which can be explained by the financial difficulties faced by middle-class families. A relevant explanation for the recent reduction in drop-out rate can be found in students' background and personal characteristics. If the economic situation does not improve, this could increase inequality and intergenerational social mobility (Ghignoni, 2017). In practice, the reform has attracted more students with less academic skills who are less academically oriented and therefore has not substantially changed the rate of aggregate abandonment (Ghignoni, 2017).

Gitto et al. (2016) highlight the importance of analysing not only student careers but also academic institutions. For example, universities located in Northern Italy present lower drop-out rates and drop-out rates appear to be higher in public universities than in private ones. Moreover, if it is true that student background is strongly connected to the propensity to drop-out, other structural factors are important - for example, the high number of universities with remote campuses and the number of courses taught at those branches. The organisational aspects of the universities and service - for example the number of teachers per student - also influence the probability of drop-out (Gitto et al., 2016). 


\subsubsection{Context analysis}

The University of Sassari is an Italian medium-sized State university of over 12,000 students and with a 455-year tradition It is located in the north west of Sardinia, in a city of around 130,000 inhabitants. Research, discovery and promotion of knowledge are core activities of the university, which offers a wide range of undergraduate and graduate programmes.

In this paper a panel of undergraduate full-time students that enrolled at the University of Sassari (Sardinia) in September 2008 is analysed. The study has been restricted to this group in order to observe the entire cycle of their academic career, which nominally should be completed in three years. The period under study is after the educational reform (2006), which means that the new guidelines have already been introduced.

Before the reform, not all departments at the University of Sassari had transformed and activated degree courses in line with the Bologna Declaration.

It is worth noting that students enrolled in a single-cycle degree course, i.e. a 5-6years programme, have not been included in the analysis as they would not graduate within the period under study. These programmes consist of 300 education credits. We have included only the programmes that consists of 180 education credits in the first cycle.

The study has analysed data from all departments at the University of Sassari: Agriculture; Architecture, Design and City Planning; Chemistry and Pharmacy; Law; Biomedical Sciences; Economic and Business Sciences; Medical, Surgical, Experimental Sciences; Humanistic and Social Sciences and History, Human Sciences, Education. Therefore, it has a representative sample of most of the student population there. As previously mentioned, the Department of Medicine has not been entirely included as degrees in Medicine and Dentistry take 6 years; however, other health and care degrees within the Deparement (nursing and paramedic degrees) have been considered. Equally, the department of Veterinary Medicine has not been included due to the 6-year duration of its degrees. Finally, bachelor degrees provided by the Department 


\section{Methods}

The study analysed data collected by the Bureau of Research at the University, including:

- Student sociodemographic data (age, gender, family background; student education background) and, in particular, residential and commuter statuses.

\section{- Student satisfaction}

Since 2001 the Bureau of Research of the University has collected evaluations from students about their satisfaction. Anonymous self-administered questionnaires are collected in class towards the end of each semester. Completion is optional and over 20,000 questionnaires are analysed each year. The evaluation is based on a 1-5 scale where 1 (one) represents the lowest value for the item and 5 (five) represents the highest. The questionnaire is mainly composed of three areas: 1) Organizational aspects of the course 2) Teaching and study activities 3) Infrastructure 4) Overall assessment (Table1).

A wide body of literature supports student evaluation as a useful instrument to measure the quality and effectiveness of teaching in higher education (Kemran, 2016; Marsh, 2007; Abrami et al., 2007; Theall and Feldman, 2007). Although most universities collect vast amounts of 
student feedback using a wide range of evaluation tools (Tucker, 2014), globally there is a lack of published research on the quality of student feedback and on what students say (Hirschberg et al., 2011; Tucker, 2014). However, there is agreement that student comments provide valuable insights into their experience and the quality of teaching (Lewis, 2001; Richardson, 2005; Hodges and Stanton, 2007; Alhija and Fresko, 2009). Despite the fact that student feedback can be useful in informing and enhancing teaching performance, Richardson (2005) highlights that, for a number of reasons, many institutions and teachers do not use student feedback to implement useful changes. The use of student feedback as an instrument to measure teaching quality was justified by Beltyukova and Fox (2002) who argued that student success, retention and development are closely linked to student satisfaction.

- Department Research quality. Finally, the research quality of the departments under study is taken into account. The study employs a composite index calculated by the National Agency for the Evaluation of the University System and Research (ANVUR) in Italy. The index measures the "distance" between the research productivity of a given department and the median productivity in the same field at national level.

\section{Table 1}

\section{Empirical approach}

The variable of interest of this study is "being" or "not being" a student that takes more than three years to obtain a degree. It is clearly a binary response variable since it can be defined by 1 , if there is delayed graduation or by 0 , otherwise 
Given the characteristics of this variable, the present study proposes a probit model, as it is appropriate for binary variables and it allows to model the probability to finish the university programme in the nominal duration according to a set of explanatory variables that can be divided into three groups. In Probit model the goodness of fit, namely the Akaike Information Criterion (AIC), the Bayesian Information Criterion (BIC), and the percentage of correct prediction (PCP), is higher compared to Logit approach ${ }^{1}$. The first group includes the inherent characteristics of the student such as gender (Male $=1$ if the student is male; zero otherwise) and age (Age). Furthermore, five dummy variables represent students' (upper) secondary studies (Other institutes, Technical secondary institute, Professional secondary institute, Teacher training school, Lyceum). The final score of such secondary studies is also included, calculated on a 100 points scale (Diploma_mark). In the second group the variables considered are family and geographical factors such as place of origin (Residential=1 if he/she comes from a village/city which is placed more than $30 \mathrm{~km}$ from the university; zero otherwise ${ }^{2}$ ) and family's average income (Income). The third group includes environmental variables that could affect student performance. More precisely, it focuses on those variables that directly relate to the quality features of the departments such as number of teachers per student (Teacher_ps), quality of research (DipQR) and students' opinions about teaching and environmental quality (Study_load; Organization; Teacher_availability; Infr_quality). A positive result is expected for all these variables. Since a positive students' evaluation can be driven by "generous" marks, which in turn can prevent a delayed graduation (Taylor et al., 2007), endogeneity problems may occur. To avoid this, the indicators are analysed using their difference between 2008/2009 and 2011/2012, which represent the beginning and the end of the period under study respectively. Table 2 shows the descriptive statistics of the variables under study.

\footnotetext{
${ }^{1}$ Probit model provides the following values: $\mathrm{AIC}=1465.912, \mathrm{BIC}=1531.721$ and $\mathrm{PCP}=0.661$. Logit model shows the following ones: $\mathrm{AIC}=1466.433, \mathrm{BIC}=1532.241$ and $\mathrm{PCP}=0.659$.

${ }^{2}$ The distance threshold has been set at 30 kilometres since it is the average radius of Sassari's commuter belt (Rete metropolitana di Sassari). Different thresholds are also tested but the main results still hold.
} 


\section{$\underline{\text { Table } 2}$}

\section{Results}

Students come mainly from high schools (more than 58\%) or technical secondary institutes (more than 24\%). Furthermore, $70.8 \%$ of them are residential students, which means that they come from a place further than $30 \mathrm{~km}$ from the University. In other words, this group of students cannot commute and need to find accommodation at the campus or the neighbouring structures. The dataset contains other relevant information, such as family income and final mark at secondary school. According to the data, $62.8 \%$ of students who enrolled in 2008 completed their degree in more than three years.

Table 3 and Table 4 report the marginal coefficients of the probit estimations. According to the first analysis (Table 3) the main factors that play a part in reducing the probability to be late in graduation are: final mark at secondary school, quality of departments' research, number of teachers per student and students' overall satisfaction. In particular, an increase of $1 \%$ in the final mark leads to a decrease of $0.0058 \%$ in the likelihood of not finishing the university programme within the nominal time (column 1). However, this variable suffers from a well-known endogenous problem. Following the famous example in Wooldridge (2010), the final mark at secondary school and the probability to end the undergraduate programme as soon as possible depend on an unobservable variable, namely ability. This issue has been taken into account when deciding to only include the growth rate of this variable from one year to the next among the controls set.

It has also been observed that departments features are relevant: the higher the environment 
quality of the department, the higher the likelihood that students exhibit a good performance. Students in departments with a higher quality research standard have a higher probability of finishing their studies within the nominal duration $(\operatorname{Dip} Q R=-0.25)$. A higher number of teachers per student also helps students to finish their studies in the expected time (Teacher $p s=-0.037$ ). Finally, the overall satisfaction of students affects behaviour to the extent that a higher students' satisfaction is associated with a lower probability to end up studying for longer than the nominal time $($ Satisfaction $=-3.32)$.

Average income of families has a very small negative effect, but still significant at 0.10 level, on the variable of interest (Income $=-2.6 \mathrm{e}-07$ ). The place where students live shows the opposite effect and allows to confirm that those students who moved to Sassari to attend their chosen programme are more likely to end their studies in more than three years $($ Residential $=0.12)$.

Still focusing on table 3, a discussion of the interaction terms enables an analysis of the relationship between some of the variables under study. Looking at columns 2-4, one can see the interaction effect between the continuous variable age and the male dichotomy. It seems that male students have, on average, a lower rate of success (Male $=0.29$ ), although this effect decreases as their age increases $($ Age*Male $=-0.016)$. Furthermore, it is observed that male residential students are, on average, more likely to finish their studies in the given time than the female group $($ Male*Residential $=-0.13)$. Finally, no empirical evidence was found on the interaction between income and residential status. Therefore, the negative performance in terms of career duration among residential students is not due to low-income issues.

As anticipated in Section 2, this study considered the set of the sub-indicators that represent the subjective satisfaction of students in the following areas: Organization, Teaching and study activities, and Infrastructure. Table 4 provides the above-mentioned estimates.

All these sub-indicators, except Teacher_availability, do not exhibit any significant effect on students' performance, although all the coefficients have the expected sign. From these results it 
appears that the availability of teachers and TAs are relevant in explaining students' careers (Teacher_availability $=-5.99)$.

\section{$\underline{\text { Table } 3}$}

\section{$\underline{\text { Table } 4}$}

\section{Robustness check}

A concern that arises in the analysis of student performance is that some variables could not be exogenous. More precisely, the observed difference in careers between residential and commuter students may be driven by other variables rather than by their residential difference. This empirical issue is called sample selection bias. A convincing argument is given by Table 4, which shows the descriptive statistics of all the variables under study for the two groups: commuter and residential students. According to the pairwise t-tests (third column), the two groups are different in a number of variables, namely Income, Age, Male, secondary education (Lyceum, Teachers_institute, Other_institute) and department features (Department Research Quality DRQ, Students Satisfaction, Organization, Teacher_availability). A possible solution to this problem is provided by Propensity Score Matching, PSM (Rosenbaum and Rubin, 1983). When considering residential differences, the ideal analysis would consider a sample of observations, which are identical except for the observed characteristics. The difference in the outcomes of the "treated" sample and the "control" sample can then be correctly attributed to the variable under study.

The PSM technique is applied to obtain unbiased estimates of the residential effects on the students' careers. The matching technique is to select a control group of commuter students that are similar to the treated ones, i.e. residential students. In the first stage a probit regression is 
estimated on the data set using measurable variables of the characteristics of the students to predict the likelihood of being in the treated group. The estimated parameters are used to calculate the fitted probabilities of being a male. These fitted values are known as the propensity scores.

To do this, the teffects psmatch command (STATA13) has been employed. The estimated coefficient associated with the residential feature equals to $0.111(\mathrm{sd}=0.039$ and $\mathrm{p}$-value $=$ 0.004). As is evident from the results above, although the Residential coefficient is smaller than that obtained in the previous standard estimations, it is still statistical significant and its sign is consistent. These results are confirmed by graphical representation of the degree of overlap, which clearly show that problems of overlap do not appear in this dataset ${ }^{3}$.

Another way to deal with a sample selection bias is proposed by Blinder (1973) and Oaxaca (1973). The so-called Blinder-Oaxaca decomposition is a methodology used to study wages differences between groups (sex, race, etc.). This approach divides the observed output differential between the groups into two parts: the first one is "explained" by group differences in individual characteristics (e.g. education or age), while the second one represents the "unexplained" component, which accounts for both a measure for discrimination and the group differences in unobserved predictors.

\section{$\underline{\text { Table } 5}$}

The oaxaca command is performed in STATA13. Table 6 shows the results of the BlinderOaxaca decomposition. The mean share of delayed graduation is 0.547 for commuter students and 0.661 for residential students, yielding a statistically significant gap of -0.116 . This gap is divided into two components. The first part represents the mean increase in residential students' performance if they had the same characteristics as commuter ones, namely Income, Age, Male,

\footnotetext{
${ }^{3}$ The graphics are available upon request.
} 
Lyceum, Teachers_institute, Other_institute, DipQR, Satisfaction, Organization, Teacher_availability. However, such differences account for only a 0.0024 increase in students' performance. In fact, such a small number is not statistically significantly different from zero. So, the differences in endowments account for an insignificant part of the performance differential while a gap of -0.118 remains unexplained. This analysis confirms what we have found with the PSM technique: the difference in performance between the two groups remains even after controlling for potential selection bias.

\section{$\underline{\text { Table } 6}$}

\section{Discussion}

The present analysis documents the main factors in explaining the performance of undergraduate students, using the University of Sassari as a case study.

It emerges that students' satisfaction, both in terms of teaching and environmental features, has a positive influence on their performance (Marsh, 2007; Abrami et al., 2007; Theall and Feldman, 2007). This result is in line with the empirical literature (see, amongst others, Kemran and Lord, 1991; Hartman and Schmidt, 1995; Machado et al., 2011) that highlights the importance of student satisfaction in improving the efficacy of their performance at university and their future employability. As Taylor et al. (2007) and Waggoner and Goldman (2005) discussed, a winning strategy to improve student satisfaction and reputation is to encourage higher levels of success and graduation rates.

Student satisfaction assessment should also explore issues related to the status of residential and commuter students while, at the same time, collecting their suggestions to involve them more actively. 
The paper also gives some indication as to the individual and background factors that support the students' performance. These relevant factors were highlighted by Gitto el al (2016) and the previous literature on the topic cited in the framework of the paper.

Another important factor that needs to be considered is the distance between students' homes and universities (e.g., Gitto et al., 2016; Cingano and Cipollone, 2007; D’Hombres, 2007).

We find that residential students are more at risk of underperformance than their commuter peers.

According to Gitto et al (2016) residential students are more likely to enrol at University without taking into consideration self-motivation and commitment, and personal academic skills, probably in relation to the low expenses that they anticipate having to bear, compared to their commuter peers.

It is important to consider that universities fees do not represent an obstacle for residential students; in fact, tuition fees in Italy are generally lower than in other countries in Europe. Average tuition fees for a higher public education in Italy are between $€ 0-1.500 €$ per year. Academic fees are linked to student's family income and academic performance (Agasisti and Murtinu, 2016).

On the other hand, commuter students could be more conscious of the implication of being enrolled to the University, for example in relation to expenses and family pressures to complete their degrees.

Future researches should further investigate student's attitudes for these two types of students with the purpose of providing services focused on the different learning and vocational requirements.

There is no strong evidence of differences between commuter and residential students, 
particularly in European Universities. In addition, there is a small amount of research focusing on the differences between the academic performance of commuter and residential students, some of which contradicts the results of the present study.

In fact, several studies highlight (Jacoby, 2000; Newbold, 2011) the advantages and benefits for residential students. For example, they have easier access to university services and facilities, they are more involved with student community building and they can receive more support from the student network. Moreover, they do not spend time and effort travelling from their residence to University.

Other research, such as Gianoutsos and Rosser (2014), show that there are practically no differences in terms of academic performance among commuter and residential students. However, it should be considered that most of these studies are focused on the American University System, which is vastly different from the European system, and even more so in comparison to the Italian system. The culture of student campus life tyipical of Amercan universities is absent in Europe.

This should be translated into a higher effort by the institution to rectify this gap. This research highlights the need to calibrate the teaching provision in response to the various typologies of students, e.g. residential and commuter students, full-time and part-time students, students with and without disabilities. It is important to support all groups according to their needs, in order to facilitate and increase the sense of community among students, which will help them to improve their productivity and well-being (Bowles and Brindle, 2017).

This study emphasises the role played by Departments' research quality: the empirical evidence shows that high research productivity is positively correlated with the likelihood for students to finish in time. Moreover, the number of professors per students, taken here as a proxy of teaching supports, has a positive effect on the ability of students to finish their graduate studies within the given period. High teaching standard is positively correlated with student 
performance, as in Beltyukova and Fox (2002). A direct policy implication of these findings is that supporting academic staff and potentiating their performance in both research and teaching, has a positive effect on student performance. It would also be desirable to involve students in research projects in order to stimulate their active learning and skills development (Healey, 2005).

Finally, the higher productivity of commuter students compared to residential ones could be due to a sample selection bias. In other words, good students might prefer to complete their studies in institutions outside of Sardinia. This effect could be stronger among the incoming students since their opportunity cost is higher than it is for students from Sassari. This result is quite surprising since both the theory and the previous experimental investigations and surveys show a different relationship. A straightforward policy implication seems to be that the University of Sassari should promote new services in order to balance the situation between residential and commuter students and filling up such a gap.

Services should be made available and promoted to students by trying to finalise some specifics for commuter students to engage in university community building. Furthermore, it is important to annually monitor students' performance and satisfaction linked to a specific university service. This would enable a greater understanding as to which services are useful to prevent student drop-out (Bennet, 2003). At the same time, the implementation of activities supporting the professional identity of students during their degree could be recommended. Such activities would mitigate demotivation and student inactivity (Sweitzer, 2009).

A possible rationale for this controversial outcome is the fact that the quality level of services provided by the University of Sassari is not sufficient to give the same opportunity to the two groups. Students who move to live on the campus or nearby might have high costs in terms of adaptation to their new environment. This may have had some influence on their productivity. In this sense, it is important to increase funding in order to support student performance (Jacoby, 
2000). Another reason could be the presence of a sample bias. Students with better results at school prefer to complete their studies outside of Sardinia. This is even more true for students coming from outside of Sassari, since the difference between the expenditures associated with the two options, i.e. stay in Sardinia or move to another university in the North of Italy or abroad, is lower.

Students' ability to complete the degree programme within the nominal duration is an important issue in Italy since it is used by MIUR as a proxy of teaching performance. Therefore, students' behaviours impact on university system transfers. In this framework, the findings of this study can be a tool for university policies aimed at helping and supporting students during their careers. These findings will enable the promotion and elaboration of new strategies that satisfy student expectations and encourage a supportive and collaborative relationship between teachers, administration and students (OECD, 2002) (Bussu et al., 2018). However, this analysis should be replicated in other Italian universities in order to depict a clearer picture of the whole Italian system.

In alignment with Burgalassi et al. (2017), it is the authors' belief that Italian universities should strengthen services and facilities to support the degree choices of students and should consolidate their collaboration with high schools. In addition, Universities should promote ongoing guidance activities to support student self-management and self-determination (Lizzio and Wilson, 2005), and should implement new projects and training to develop student life skills, such as decisionmaking and problem-solving, aimed at increasing confidence in the management of daily life problems. Finally, it may be useful to rethink services and projects based on students' statuses (residential versus commuter or full-time versus part-time) and training needs. 


\section{Conclusions and implications}

This paper contributes to the international ongoing discussion on the development and implementation of teaching methods to support student performance. Notably, both students and university will benefit from these practices. Determining the main factors of student careers (in terms of duration, performance or drop-out) can help to identify new strategies and to design appropriate actions that support the student community. For all these reasons, this paper is not only of interest for the academic community, but it could also be useful for policy makers to identify strategies and incentives to improve student well-being and performance.

In view of the results emerged, it is the authors' belief that future research should be focused on student's attitudes and study propensities, particularly for two types of groups: residential and commuter students. Moreover, secondary education and higher education institutions should consider motivational and psychological support services focused on personal needs of different types of students.

Furthermore, in consideration of the direct relationship between research quality and performance students (i.e. to complete their degree in time), it is deemed crucial that lecturers have adequate time to implement research quality that they can transmit to their students. Lecturers over first year students enrolled is inversely and significantly correlated to dropouts (Gitto et a., 2016). For this reason, National government should increase permanent staff academic recruitment.

In conclusion, this research could be extended in order to analyse the moment in time where it is more frequent for students to fail in their university careers. For instance, Dekker et al. (2014) highlights that a higher drop-out rate is observed during the first year of study. One reason can be that students do not adapt to the new university environment. Alternatively, it could be a simple problem of matching between students and institutions: working with a limited set of information, students have a higher likelihood to commit a mistake during their first year than in 
subsequent years. Thus, in future analysis it could be very useful to analyse this issue in order to devise some strategies for motivating and involving students in the university context (Leveson et al., 2013). 


\section{References}

Abrami, P. C., D'Apollonia, S. and Rosenfield, S. (2007). "The dimensionality of student ratings of instruction: What we know and what we do not", in Perry R. P. and Smart J. C. (Eds.), The scholarship of teaching and learning in higher education: An evidence based perspective, Springer, Dordrecht, pp. 385-445.

Agasisti T. and Murtinu S.(2016). Grants in Italian university: a look at the heterogeneity of their impact on students' performances, Studies in Higher Education, Vol 41 No. 6, pp. 11061132.

Aikens, N. L. and Barbarin, O. (2008), Socioeconomic Differences in Reading Trajectories: The Contribution of Family, Neighbourhood, and School Contexts, Journal of Educational Psychology, Vol. 100 No. 2, pp. 235-251.

Alfano, H. L. and Eduljee, N. B. (2007), Differences in work, levels of involvement, and academic performance between residential and commuter students. College Student Journal, Vol. 47 No. 2, pp. 334-342.

Alhija, F. N. and Fresko, B. (2009), Student evaluation of instruction: What can be learned from students' written comments? Studies in Educational Evaluation, Vol. 35 No. 1, pp. 37-44.

Beltyukova, S. A., and Fox, C. M. (2002),Student satisfaction as a measure of student development: Towards a universal metric, Journal of College Student Development, Vol. 43 No. 2, pp. 161-172.

Belloc, F. Maruotti A. and Petrella, L (2011), How individual characteristics affect university students drop-out: a semiparametric mixed-effects model for an Italian case study, Journal of Applied Statistics, Vol. 38 No. 10, pp. 2225-2239.

Belloc, F. Maruotti A. and Petrella, L (2010), University drop-out: an Italian experience. High Educ., Vol. 60, pp. 127-138.

Bennet, R. (2003), Determinants of Undergraduate Student Drop Out Rates in a University Business Studies Department, Journal of Further and Higher Education, Vol. 27, pp. 123-141.

Blinder, A. S. (1973), Wage discrimination: Reduced form and structural estimates, Journal of Human Resources, Vol. 8, pp. 436-455.

Bond, C. H. (2000), The development of students' experiences of learning in higher education. Unpublished Ph.D. thesis, Griffith University, Queensland.

Boero, G., Laureti, T., and Naylor, R. A. (2005), An econometric analysis of student withdrwal and progression in the post-reform Italian univerisities. CRENOS Working paper, no. 1048.

Bowles, T.V. and Brindle, K. A. (2017), Identifying facilitating factors and barriers to improving student retention rates in tertiary teaching courses: a systematic review, Higher Education Research and Development, Vol. 36 No. 5, pp. 903-919. 
Burgalassi M., Biasi, V. Capobianco, R. and Mopretti, G. (2017), Il fenomeno dell'abbandono universitario precoce. Uno studio di caso sui corsi di laurea del Dipartimento di Scienze della Formazione dell'Università "Roma Tre". Italian Journal of Educational Research, Vol. 17, pp. 105-126.

Bussu, A., Veloria, C. N. and Boyes-Watson, C. (2018), StudyCircle: Promoting a Restorative Student Community, Pedagogy and the Human Sciences, Vol. 6 No. 1, pp. 1-20. Retrieved from https://scholarworks.merrimack.edu/phs/vol6/iss1/6

Chickering, A.W. (1974), Commuting vs. residential students: Overcoming educational inequities of living off campus, Jossey-Bass, San Francisco.

Choi, B. K. and Rhee, B. S. (2014), The influences of student engagement, institutional mission, and cooperative learning climate on the generic competency development of Korean undergraduate students, Higher Education, Vol. 67 No. 1, pp. 1-18.

Cingano, F., \& Cipollone, P. (2007), University drop-out: The case of Italy. Temi di discussione, Banca D'Italia, No. 626, pp.1-33.

Coate, K., Barnet, R. and Williams, G. (2001), Relationships Between Teaching and Research in Higher Education in England, Higher Education Quarterly, Vol. 55 No. 2, pp. 158-174.

Costantini, P. and Vitale, M.P. (2010), "Analyzing Undergraduate Student Graduation Delay: A Longitudinal Perspective", in Attanasio, M. and Carpursi, V. (Eds), Statistical Methods for the Evaluation of University Systems. Part of the series Contributions to Statistics, Springer, Berlin, pp. 145-159.

Dekker, G.W., Pechenizkiy, M. and Vleeshouwers, J.M. (2014), Predicting Dropout Student: An Application of Data Mining Methods in an Online Education Program, European Journal of Open, Distance and E-Learning, Vol. 17 No. 1, pp. 118-133.

D'Hombres, B. (2007), The impact of university reforms on dropout rates and students'status: Evidence from Italy, JRC Scientific and Technical Report, No. 40507, 1-36.

Dion, D. P. (2005), The Lisbon Process: a European Odyssey, European Journal of Education, Vol. 40 No. 3, pp. 295-313.

Di Pietro, G. and Cutillo, A. (2008), Degree flexibility and university drop-out: The Italian experience, Econom. Educ.Rev, Vol. 27, pp. 546-555.

Dugan, J.P., Garland, J.L., Jacoby, B. and Gasiorski, A. (2008). Understanding commuter student self-efficacy for leadership. A within-group analysis. NASPA Journal, Vol. 45 No. 8, pp. 282-310.

European Commission (2009). Progress toward the Lisbon Objectives in Education and Training- Indicators and Benchmarks 2009, Brussels, European Commission.

European Commission (2010). Joint Report by the Economic Policy Committee (Quality of Public Finances) and the Directorate-General for Economic and Financial Affairs of European Commission, European Economy Occasional Papers, Brussels, European Commission. 
Eurostat (2014), Share of young adults having completed tertiary education up to $37 \%$. Luxembourg, Office of the European Union, Luxembourg.

Eurydice (2010), Focus on Higher Education in Europe 2010: the impact of the Bologna Process. Resource document. Education, Audiovisual and Culture Executive Agency (EACEA P9 Eurydice), retrieved from http://www.eurydice.org.

Ghignoni, E. (2017), Family background and university dropouts during the crisis: the case of Italy, Higher Education, Vol. 73 No. 1, pp. 127-151.

Gibbs, G. (1995), The Relationship Between Quality in Research and Quality in Teaching, Quality in Higher Education, Vol. 1 No. 2, pp. 147-157.

Gitto L., Minervini L. F. and Monaco L.(2016), University dropouts in Italy: Are supply side characteristics part of the problem, Economic Analysis and Policy, Vol. 49, pp. 108-116.

Gianoutsos, D. and Rosser, V., (2014), Is there still a considerable difference? Comparing residential and commuter student profile characteristics at a public, research, commuter university, College Student Journal, Vol. 48 No. 4, pp. 613 -628.

Gianoutsos, D. (2011), Comparing the student profile characteristics between traditional residential and commuter students at a public, research-intensive, urban community university. Doctoral dissertation, University of Nevada-Las Vegas, retrieved from: http://digitalscholarship.unlv.edu/thesesdissertations/925

Grilli L., Rampichini C. and Varriale R. (2016), Statistical modelling of gained university credits to evaluate the role of pre-enrolment assessment tests: An approach based on quantile regression for counts, Statistical Modelling, Vol. 16 No. 1, pp. 47-66.

Hattie, J. and Marsh H. W. (1996), The Relationship Between Research and Teaching: A MetaAnalysis, Review of Educational Research, Vol. 66 No. 4, pp. 507-42.

Hanushek, E.A. and Rivkin, S.G. (2006), "Teacher Quality", in Hanushek E.A. and Welch F. (Eds.), Handbook of the Economics of Education, Elsevier, Amsterdam, North-Holland, pp.1-29

Hartman, D.E. and Schmidt, S. L. (1995), Understanding student/alumni satisfaction from a consumer's perspectives: the effects of institutional performance and program outcomes, Research in Higher Education, Vol. 36 No. 2, pp. 197-217.

Healey, M. (2005),Linking Research and Teaching to Benefit Student Learning, Journal of Geography in Higher Education, Vol. 29 No. 2, pp. 183-201.

Healey, M. and Roberts, J. (Eds) (2004), Engaging Student in Active Learning: Case Studies in Geography, Environment and Related Disciplines (Cheltenham: Geography Discipline Network and School of Environment, University of Gloucestershire), retrieved from: http://www2.glos.ac.uk/gdn/active/student.htm. 
Heublein, U. (2014), Students drop-out from German Higher Education Institutions. European Journal of Education, Vol. 49, No. 4, pp. 498-513.

Hodges, L. C. and Stanton, K. (2007), Translating comments on student evaluations into the language of learning. Innovative Higher Education, Vol. 31 No. 5, pp. 279-286.

Horn, L.J. and Berktold, J. (1998), Profile of undergraduates in U.S. postsecondary education institutions: 1995-96. Office of Educational Research and Improvement, U.S. Department of Education, Washington, DC.

Jacoby, B. (2000), Why Involve Commuter Students in Learning? New Directions for Higher Education, Vol. 2000 No.109, pp 3-12.

Jung, J. and Kim, Y. (2017), Exploring regional and institutional factors of international students' dropout: The South Korea case, Higher Education Quarterly, Vol. 72 No. 2, pp. 1-19.

Johnes, G. and McNabb, R. (2004), Never Give up on the Good Times: Student Attrition in the UK. Oxford Bulletin of Economics and Statistics, Vol. 66 No. 1, pp. 23-47.

Kemran, M. (2016), Why students drop out of the Bachelor of Arts. Higher Education Research and Development, Vol. 35 No. 5, pp. 983-996.

Kernan, M.C. and Lord, R. G. (1991), An Application of Control Theory to Understanding the Relationship Between Performance and Satisfaction, Human Performance, Vol. 4 No.3, pp. 173185.

Kuh, G.D., Gonyea, R.M. and Palmer, M. (2011), The Disengaged Commuter Student: Fact or Fiction? Commuter Perspectives, Vol. 27 No. 1, pp. 2-5.

Lee, R. (2004), Research and teaching: making - or breaking - the links, Planet, Vol. 12 No. 4, pp. $9-10$

Leveson, L., McNeil, N. and Joiner, T. (2013), Persist or withdraw: The importance of external factors in students' departure intentions, Higher Education Research and Development, Vol. 32 No. 6, pp. 932-945.

Lewis, K. G. (2001), Making sense of student written comments, New Directions for Teaching and Learning, Vol. 2001 No. 87, pp. 25-32.

Lizzio, A. and Wilson, K. (2005), Self-managed learning groups in higher education: Students' perceptions of process and outcomes, Br J Educ Psychol., Vol 73 No. 3, pp. 373-390.

Machado, M., Brites, R. , Magalhães, A. and Sá, M. J.(2011), Satisfaction with Higher Education: critical data for student development, European Journal of Education, Vol 46 No. 3 , pp. 415- 432.

Malcolm, M. (2014), A Critical Evaluation of Recent Progress in Understanding the Role of the Research-Teaching Link in Higher Education, Higher Education, Vol. 67 No. 3, pp. 289-301. 
Marsh, H. W. (2007), "Students' evaluations of university teaching: Dimensionality, reliability, validity, potential biases and usefulness", in Perry, R. P. and Smart J. C. (Eds.), The scholarship of teaching and learning in higher education, Springer, Dordrecht, pp. 319-383

Mega, C., Ronconi, L. and De Beni, R. (2014), What Makes a Good Student? How Emotions, Self-regulated Learning, and Motivation Contribute to Academic Achievement, Journal of Educational Psychology, Vol. 106 No. 1, pp. 121-31.

Newbold, J.J., Mehta, S.S. and Forbus, P. (2011), Commuter students: Involvement and identification with an institution of higher education, Academy of Educational Leadership Journal, Vol. 15 No. 2, pp. 141-153.

Noser, T.C., Manakyan H. and Tanner J. R. (1996), Research productivity and perceived teaching effectiveness: A Survey of Economics Faculty, Research in Higher Education, Vol. 37 No. 3, pp. 299-319.

Oaxaca, R. (1973), Male-female wage differentials in urban labor markets. International Economic Review, Vol. 14 No.3, pp. 693-709.

OECD, (2002), Responding to Student Expectations. OECD Publications Service, Paris, France.

Pocklington, T.C. and Tupper, A. (2002), No place to learn: Why universities aren't working, UBC press, Vancouver.

Quinn, J. (2013), Drop-out and Completion in Higher Education in Europe among Students from Under-represented Groups. NESET, Bruxelles.

Raponi V., Martella, F. and Maruotti, A. (2016), A biclustering approach to university performances: an Italian case study. Journal of Applied Statistics, Statistics in Education, Vol. 43 No.1, pp. 31-45.

Richardson, M. Abraham, C. and Bond, R. (2012), Psychological Correlates of University Students' Academic Performance: A Systematic Review and Meta-analysis, Psychological Bulletin, Vol. 138, No 2, pp. 353-87.

Robertson, J. and Bond C.H. (2001), Experiences of the Relation between Teaching and Research: What do academics value? Higher Education Research \& Development, Vol. 20 No.1, pp. 5-19.

Rosenbaum, P. R. and Rubin, D. B. (1983), The Central Role of the Propensity Score in Observational Studies for Causal Eects, Biometrika, Vol. 70 No.1, pp. 41-55.

Schnepf, S.V. (2015), University dropouts and labor market success, IZA World of Labor, Institute for the Study of Labor (IZA), Bonn, No. 182, pp.1-10, retrieved from http://dx.doi.org/10.15185/izawol.182

Scott, P. (2002), High wire, Education Guardian, p. 13. 
Snyder, T.D. and Dillow, S.A. (2011), Digest of Education Statistics 2010 (NCES 2011-015). U.S. Department of Education, National Center for Education Statistics. Washington, DC, Retrieved from http://nces.ed.gov/pubs2011/2011015.pdf.

Sweitzer, V. (2009), Towards a Theory of Doctoral Student Professional Identity Development: A Developmental Networks Approach, The Journal of Higher Education, Vol. 80 No. 1, pp. 133.

Taylor, J., Brites, R., Correia, F., Farhangmehr, M., Ferreira, B., Machado, M. L., Sarrico, C. and $\mathrm{Sa}^{\prime}$, M. J. (2007), Strategic enrolment management: improving student satisfaction and success in Portugal, Higher Education Management and Policy, Vol. 20 No. 1, pp.120-137.

Theall, M. and Feldman, K. A. (2007), Commentary and update on Feldman's (1997) identifying exemplary teachers and teaching: Evidence from student ratings, in Perry R. P. and Smart J. C. (Eds.), The scholarship of teaching and learning in higher education, Springer, Dordrecht, pp. $130-143$.

Thiele T., Singleton A., Pope, D. and Stanistreet, D. (2016), Predicting students' academic performance based on school and socio-demographic characteristics, Studies in Higher Education, Vol. 41 No. 8, pp. 1424-1446.

Triventi M. and Trivellato P. (2009), Participation, performance and inequality in Italian higher education in the 20th century, Higher Education, Vol. 57 No. 6, pp. 681-702.

Tucker, B. (2014),Student evaluation surveys: anonymous comments that offend or are unprofessional. Higher Education, Vol. 68 No. 3, pp. 347-358.

Waggoner, D. and Goldman, P. (2005), Universities as communities of fate. Institutional rhetoric and student retention policy, Journal of Education Administration, Vol. 43 No.1, pp. 86-101.

Weissberg, N.C., Owen, D.R., Jenkins, A.H. and Harburg, E. (2003), The incremental problem: Enhancing the predictability of academic success in an urban, commuter institution. Genetic, Social, and General Psychological Monographs, Vol. 129 No. 2, pp. 153-180.

Wooldridge, J. M. (2010), Econometric Analysis of Cross Section and Panel Data, The MIT Press, London, UK.

Young, P. (2006), Out of balance: lecturers' perceptions of differential status and rewards in relation to teaching and research, Teaching in Higher Education, Vol. 11 No. 2, pp. 191-202.

Zotti, R. (2015). Should I Stay Or Should I Go? Dropping Out From University: An Empirical Analysis Of Students' Performances. Working Papers 70, AlmaLaurea Inter-University Consortium.

Retrieved from http://www2.almalaurea.it/universita/pubblicazioni/wp/pdf/wp70.pdf. 


\begin{abstract}
Purpose: Research on the association between individual characteristics of undergraduate students, drop-out and delayed graduation is still evolving. Therefore, further evidence is required.

Design/methodology/approach: This paper reports on an empirical study examining the relationship between students' individual characteristics and delayed graduation. The analysis is based on a sample of 1167 students who have registered on and have completed a full-time undergraduate program in Italy. Using a Probit model, the findings document the individual, background and environmental indicators that play a role in explaining delayed graduation.
\end{abstract}

Findings: The study observes that students who commute to university perform better than those residing on campus. Other factors increasing the probability of completing the undergraduate programme on time include individual characteristics (e.g. gender and age), student background (family income, education), institutional environment (teaching and research quality) and student satisfaction. Finally, some policy implications are discussed.

Social implications: A direct policy implication of these findings is that supporting academic staff in order to enhance their performance in both research and teaching has a positive effect on the performance of the students.

Originality/value: This paper contributes to the debate on the impact of institutional quality on students' performance, aiming to address the question of balance between teaching and research orientation.

Keywords: Undergraduate; drop-out; delayed graduation; student satisfaction; teaching and research quality. 


\section{Introduction}

The Lisbon Strategy (March 2000), the Bologna process (Eurydice, 2010) and the training priorities provided by Europe 2020 (EU2020) are committed to the establishment of a knowledge economy that promotes employability and the development of human capital via lifelong learning and social equity (EC, 2009; Dion, 2005).

One of EU2020's top priorities is to see an expansion of education at all levels throughout Europe, with two specific goals: to reduce school drop-out by $10 \%$ and to increase the number of adults between the ages of 30 and 34 in higher education by $40 \%$. These are no trivial goals for Italy given the declining numbers of students enrolling onto undergraduate programmes and the increasingly long time it takes for them to complete their degrees. According to Eurostat (2014), Italy ranks towards the lower end of the spectrum in respect of its graduate numbers, followed only by the Czech Republic, Romania, and Slovakia. Among the $25-34$ age group, only $19 \%$ of the Italian population have obtained a bachelor's degree, compared to a European average of around $30 \%$.

According to Schnepf (2015), Italy has the highest drop-out out rate out of 15 European countries. Furthermore, the Italian student's decision to drop-out is permanent, in comparison with their European peers, who decide to return and complete their degree later in life.

In Italy, non-completion of degrees affects $40 \%$ of enrolled students, whilst in other Western European countries the figure varies between 21\% and 28\% (Quinn, 2013).

D'Hombres (2007) asserts the importance of studying the Italian case, which is characterised by high rates of university drop-out out and low graduation rates. These are important indicators of the inefficiency of the tertiary education system.

Therefore, it seems relevant to focus on the situation in Italy in order to understand which factors influence student academic behaviour and progression. Student drop-out and delayed graduation have been recognised as two important issues in higher education institutions in many European 


\section{Literature Review}

Student performance has been studied from a range of economic, psychological, and sociological perspectives in order to understand which factors affect behaviour and decision-making. Educators, academics, and policy makers have linked student performance to factors relevant to these perspectives along with the quality of higher education and the suitability of institutions for individual students (Leveson et al, 2013; Zotti, 2015; Bowles and Brindle, 2017).

In general, two main lines of research can be distinguished. The first refers to the analysis of the role played by the "macro-categories", such as the socio-educational background of the student. The second strand of research focuses on the impact of "micro-categories" on student performance. Regarding the first research area, relevant studies have identified the influence of social indicators including gender, socio-economic status, family background and ethnic group (Aikens and Barbarin 2008; Thiele et al., 2016; Ghignoni (2017). In the Italian context, Cingano and Cipollone (2007) have used national institutional data (ISTAT: Italian National Institute of Statistics) to highlight the importance of socio-familial backgrounds of students. For example, the probability of university drop-out decreases in relation to the number of years the father spends in education. This aspect emphasises the impact of parental educational background on the academic performance of their offspring. Other important determinants for student drop-out include student educational background, academic degree performance, and personal characteristics such as gender and place of residence. In this regard, Belloc et al. (2011) have showed that high drop-out probability is linked to secondary school final marks and low 
individual students' performance. Boero et al. (2005) has adopted a probit model (also used in the present research) to evaluate the impact of the Italian academic reform (2001) on students' withdrawal and progression and has demonstrated that the type of high school chosen by students and their final grade have a statistically significant effect on the probability of drop-out. Using data from the five waves of the Italian Longitudinal Household Survey, through the analysis of cross-tabulation and multinomial logistic regression models, Triventi and Trivellato (2009) found that the percentage of drop-outs is higher among high-intensity workers compared to full-time students and low-intensity workers. Italian students from upper middle classes are less likely to retire or graduate late than students in lower middle classes.

Regarding the second line of research, several studies have considered the effects of students' personal characteristics, the role of internal and external motivation, student attitude to academic study and any related employment or professional goals (Mega et al., 2014; Richardson et al., 2012).

Belloc et al. (2010) have used university administrative data to provide information on student performance. The authors do not consider the drop-out phenomenon as a binary choice set (yes or no) but offer realistic treatment of withdrawal decisions analysing several outcomes: drop-out of university, retention in the same faculty, change of faculty, change of institution. This method enables to obtain more detailed information on the type of drop-out/withdrawal and on the motivations relating to it.

Furthermore, students with lower grades and incomes of up to $10,000 €$ per year are less likely to drop-out. This can be explained by the family and financial pressures placed upon this group to conclude their studies as soon as possible. Adult students also have a lower likelihood of dropout. This could be explained by the fact that adults, and potentially workers, are more motivated to conclude their training path in time.

In respect to the ongoing debate on student performance in higher education two issues are 
highlighted as worthy of further exploration: the difference in performance between students who reside on campus and those who commute to campus, and the role played by the institutional environment (including teaching and research quality).

With regards to the first issue, comparisons between commuter and residential students have been analysed over the last four decades following the work of Chickering (1974). According to Horn and Berktold (1998) and Snyder and Dillow (2011), the majority of college students commute to campus in US. However, Jacoby (2000) found that these students were highly likely to be less involved in academic pursuits than residential students due to multiple time constraints. This could be problematic because academic engagement, e.g. interacting with academic staff and other students, has been shown to add value to the student experience (Chickering, 1974; Kuh et al., 2011; Newbold et al., 2011). However, Alfano and Eduljee (2007) who performed a survey analysis to investigate the relationship between the number of hours worked and GPA among residential and commuter students, found no statistically significant relationship. This broader comparative literature presents a plethora of research contributions involving samples of differing sizes weighted more towards students residing on campus (Dugan et al., 2008; Weissberg et al., 2003).

Understanding the difference in performance between commuter and residential students is a significant step towards identifying student groups most at risk of delayed graduation. In Italy, the aspiration of the higher education system is to increase the number of students with a degree, in line with other European countries. Within this context, it is important to study the progression of residential and commuter students to help identify and support the student group most at risk. With regards to the issue of institutional environment, research and teaching quality have already been explored in previous studies.

If the positive effects of teaching quality are well known in literature, the analysis of teachers' research performance on students' careers has not received the same attention. As pointed out by 
several scholars, research drives good teaching. Current research has focused on how the relationship between research and teaching could or should work (Malcolm, 2014; Jung and Kim, 2017).

Raponi et al. (2016) have analysed university performance with a multifactorial approach, adopting a multivariate technique (biclustering) to compare private and public universities in Italy. They have focused on different dimensions such as productivity, teaching, research and internationalisation, comparing 55 Italian Economics faculties and identifying differences between public and private universities. The study showed that private institutions present better performances compared to public universities, especially in terms of productivity and internationalisation. In addition, private professionals are very active on fund-raising and are more careful about providing human and structural services to students. Public universities are active in the internationalisation of education (incoming and outgoing students) and in implementing actions aimed at supporting students during their course of study.

Based on these findings, it would make sense to allocate increased resources to research projects rather than teaching programmes. However, the existence of a direct connection between research and teaching activity is not obvious (Gibbs, 1995). For example, in their meta-analysis Hattie and Marsh (1996) conclude that there is not a strong relationship between research and teaching performance.

Furthermore, the teaching and research dimensions are not easy to analyse as they are influenced by a number of external variables such as personal motivation and interests, time commitments and orientations to teaching (Robertson and Bond, 2001). A review of the literature has demonstrated two opposing positions. The first is that the relationship between teachers' research productivity and teaching efficacy is very low (Noser et al., 1996; Coate et al., 2001; Pocklington and Tupper, 2002). The second is that research carried out by teachers has a positive impact on students' learning (Scott, 2002; Healey and Roberts, 2004). Healey (2005) in particular showed 
there are positive benefits for undergraduate students' learning when their teachers are actively involved in research.

The incentives offered to those focusing on either teaching or research in Italy could contribute to a shift in the equilibrium. Young (2006) found that academic teachers perceived teaching as a highly demanding career with a low return in terms of salary and social status in comparison to research and other institutional activities. This aspect has been recognised to drive academics to give much more emphasis to their research as it repays more than teaching activities (Taylor et al., 2008). These aspects can lead to a situation in which an institution "specialises" in only one dimension. Analysing the impact of the two activities is a fundamental step in adopting the most appropriate approach both at institutional and national level. A number of authors have stressed the role played by the model organization and college mission on students' results and wellbeing (Thiele et al., 2016; Choi and Rhee, 2014).

\section{Paper aims and literature contribution}

This paper contributes to the debate about the impact of institutional quality on the performance of residential and commuter students, aiming to address the question of balance between teaching and research orientation.

In contrast to previous important research that utilised national data banks (Cingano and Cipollone, 2007; Triventi and Trivellato, 2009), this study includes individual characteristics collected from the administrative offices of universities - which may be potentially relevant to understand drop-out probability.

Furthermore, the paper tries to address another relevant issue that is common to many universities and other higher education institutions: the difference in performance between residential and commuter students.

The research goal is to elucidate two issues that, as far as the authors know, have not been fully 
explored yet. Firstly, it focuses on the impact of departments' features on students' performance. Although it has been demonstrated that teaching quality performance reduces students' propensity to drop-out (Kemran, 2016; Johnes and Mcnabb, 2004; Hanushek and Rivkin 2006), the understanding of the effects of research quality and productivity on students' performance appears to be limited. This analysis aims to fit into the current debate by testing the impact of research quality - measured by national indicators provided by the Italian Ministry of Education, University and Research (MIUR) - and teaching quality - proxied by students' satisfaction - on students' careers. Secondly, the research compares the performance of two groups of students: residential and commuter students (Jacoby, 2000). This research question is important because the two groups present very different needs and behaviours. For instance, one can think how their status affects the demand of services both in terms of quantity and typology (student accommodation, transports, public areas, etc.) (Bowles and Brindle, 2017).

Studies on microdata by Belloc et al. (2011); and Burgalassi et al. (2018), analyse cohorts of students from the same Italian university; however, unlike the present study, which involves all the subject areas present, they focus on singular specific departments (economics in the first case and education sciences in the second case).

In considering the impact of two relevant variables in the explanation of drop-out - teaching and research quality - neither of these studies focus on comparing the performance between residential and commuter studies as the present study does. In addition, both studies analyse data from the same large University in Rome: "Sapienza". In the present case, a medium-size and insular University, the University of Sassari (see Context analysis section) has been considered. Raponi et al., 2018 analyse the data of 55 Italian Universities but they have only included data from economics faculties in their sample. Moreover, they have not focused on the comparison between residential and commuter students. Finally, they adopted different indicators to analyse the variables of teaching and research. For example, they have not considered student 
satisfaction and the ANVUR (National Agency for the Evaluation of the University System and Research) index.

To close this gap, information about students registered in the Autumn 2008 cohort at the University of Sassari was scrutinised in the present research. The implementation of a longitudinal analysis solves any problems of data comparability over time. In fact, all students faced the same environment at the same time, which helped to model and interpret the variables under study. Firstly, the University of Sassari is a good Italian case study as it is representative of the national situation (60\% delayed graduation) (Zotti, 2015). Secondly, in the Italian context the University of Sassari is a medium-sized institution (12,000 students in 2014/2015) and a medium-ranked university. Therefore, results could be generalized to similar institutions within the Italian system.

Thirdly, the isolated condition of Sardinia dramatically reduces the outflow/inflow of students. This aspect leads to a high homogeneity among the student population. Although at first glance this seems to constitute a problem, it is advantageous for the research. The limited presence of ethnic and cultural diversity makes the pattern clearer. There are no interaction issues between our variables of interest through belonging to minority groups, avoiding possible sample and estimator biases. It is observed that residential students perform worse than commuter students defined as all students who do not live in institution-owned housing on campus. Furthermore, other factors seem to explain the success in attending an academic institution, measured here as the probability to finish the undergraduate programme within the nominal duration. These include individual characteristics (e.g. gender and age), students' background (family income, secondary schools, and final marks obtained), institutions' environment (departments' teaching and research quality) and student well-being (student satisfaction). Finally, some policy implications are discussed.

Dealing with residential and commuter students one can notice that the analyses are mostly 
based on aggregated unbalanced data in which residential institutions are often over-represented (Gianoutsos, 2011). In order to better compare the two statuses across the student population, it is necessary to analyse micro-data and use a balanced sample. The data in this study satisfies both these requirements. The sample contains micro-information of a sufficiently balanced number of commuter and residential students, 341 and 826 respectively. This allows to correctly identify and measure the impact of this status on student performance. As it will be discussed later, some policy implications could be derived from this study.

\section{Background information and data}

\subsubsection{The Italian university reform}

The current regulatory framework for the tertiary education system in Italy is the product of various reforms introduced after the post-war period and aimed at extending access to university education until the 1980s. Since 1999, the Italian academic system has been completely reformed to achieve the objectives of the Bologna Declaration. The old systems envisaged four/five-years degree programmes. The new one, introduced with the reform enacted by the MIUR decree No. 509 of 1999 (which came into effect in 2001) and completed by MIUR decree No. 270 of 2004, provides 2 main cycles. The first cycle, Laurea degree, is a three-year full-time programme with a workload of 180 ECTS credits, corresponding to the bachelor degree of the Bologna Declaration. The second cycle consists of a further two-year full-time programme to obtain 120 ECTS credits and to achieve Laurea magistrale, corresponding to the master-level degree of the Bologna Declaration. This cycle of education is supposed to prepare students for higher, managerial and professional positions (EC, 2010).

According to Ghignoni (2017), the reform aimed to increase the number of graduate students, particularly by encouraging demotivated students to obtain at least a first-level degree, and to reduce the number of years required to complete a degree. 
Through analysis of the academic careers of students during the pre-reform (1995 and 1998) and post-reform (2001) periods Di Pietro and Cutillo (2008), have evinced that the reform has contributed to changing students behaviour, reducing their probability to drop-out.

Ghignoni (2017) used a bivariate probit model and sample decomposition techniques to analyse determinants of the reduction in the drop-out rate in the Italian university system during the economic crisis. He discovered that the current drop in enrolment in Italian universities is mainly due to a differentiation in the behaviour of the middle class and the bourgeoisie. The cultural background of families maintains its influence on enrolment, but loses ground in preventing abandonment.

During the economic crisis, the drop-out probability of students coming from the middle classes has increased, which can be explained by the financial difficulties faced by middle-class families. A relevant explanation for the recent reduction in drop-out rate can be found in students' background and personal characteristics. If the economic situation does not improve, this could increase inequality and intergenerational social mobility (Ghignoni, 2017). In practice, the reform has attracted more students with less academic skills who are less academically oriented and therefore has not substantially changed the rate of aggregate abandonment (Ghignoni, 2017).

Gitto et al. (2016) highlight the importance of analysing not only student careers but also academic institutions. For example, universities located in Northern Italy present lower drop-out rates and drop-out rates appear to be higher in public universities than in private ones. Moreover, if it is true that student background is strongly connected to the propensity to drop-out, other structural factors are important - for example, the high number of universities with remote campuses and the number of courses taught at those branches. The organisational aspects of the universities and service - for example the number of teachers per student - also influence the probability of drop-out (Gitto et al., 2016). 


\subsubsection{Context analysis}

The University of Sassari is an Italian medium-sized State university of over 12,000 students and with a 455-year tradition It is located in the north west of Sardinia, in a city of around 130,000 inhabitants. Research, discovery and promotion of knowledge are core activities of the university, which offers a wide range of undergraduate and graduate programmes.

In this paper a panel of undergraduate full-time students that enrolled at the University of Sassari (Sardinia) in September 2008 is analysed. The study has been restricted to this group in order to observe the entire cycle of their academic career, which nominally should be completed in three years. The period under study is after the educational reform (2006), which means that the new guidelines have already been introduced.

Before the reform, not all departments at the University of Sassari had transformed and activated degree courses in line with the Bologna Declaration.

It is worth noting that students enrolled in a single-cycle degree course, i.e. a 5-6years programme, have not been included in the analysis as they would not graduate within the period under study. These programmes consist of 300 education credits. We have included only the programmes that consists of 180 education credits in the first cycle.

The study has analysed data from all departments at the University of Sassari: Agriculture; Architecture, Design and City Planning; Chemistry and Pharmacy; Law; Biomedical Sciences; Economic and Business Sciences; Medical, Surgical, Experimental Sciences; Humanistic and Social Sciences and History, Human Sciences, Education. Therefore, it has a representative sample of most of the student population there. As previously mentioned, the Department of Medicine has not been entirely included as degrees in Medicine and Dentistry take 6 years; however, other health and care degrees within the Deparement (nursing and paramedic degrees) have been considered. Equally, the department of Veterinary Medicine has not been included due to the 6-year duration of its degrees. Finally, bachelor degrees provided by the Department 
of Law have been considered except the degree in Law, which takes 5 years.

\subsection{Research design}

\section{Participants}

The data contain information on the individual and family background of each student, which is collected upon enrolment. The sample age ranges from 18 to 69 years - although, interestingly, more than $50 \%$ of the students are younger than 20 - and the gender breakdown is $30.3 \%$ males and $69.7 \%$ females.

\section{Methods}

The study analysed data collected by the Bureau of Research at the University, including:

- Student sociodemographic data (age, gender, family background; student education background) and, in particular, residential and commuter statuses.

\section{- Student satisfaction}

Since 2001 the Bureau of Research of the University has collected evaluations from students about their satisfaction. Anonymous self-administered questionnaires are collected in class towards the end of each semester. Completion is optional and over 20,000 questionnaires are analysed each year. The evaluation is based on a 1-5 scale where 1 (one) represents the lowest value for the item and 5 (five) represents the highest. The questionnaire is mainly composed of three areas: 1) Organizational aspects of the course 2) Teaching and study activities 3) Infrastructure 4) Overall assessment (Table1).

A wide body of literature supports student evaluation as a useful instrument to measure the quality and effectiveness of teaching in higher education (Kemran, 2016; Marsh, 2007; Abrami et al., 2007; Theall and Feldman, 2007). Although most universities collect vast amounts of 
student feedback using a wide range of evaluation tools (Tucker, 2014), globally there is a lack of published research on the quality of student feedback and on what students say (Hirschberg et al., 2011; Tucker, 2014). However, there is agreement that student comments provide valuable insights into their experience and the quality of teaching (Lewis, 2001; Richardson, 2005; Hodges and Stanton, 2007; Alhija and Fresko, 2009). Despite the fact that student feedback can be useful in informing and enhancing teaching performance, Richardson (2005) highlights that, for a number of reasons, many institutions and teachers do not use student feedback to implement useful changes. The use of student feedback as an instrument to measure teaching quality was justified by Beltyukova and Fox (2002) who argued that student success, retention and development are closely linked to student satisfaction.

- Department Research quality. Finally, the research quality of the departments under study is taken into account. The study employs a composite index calculated by the National Agency for the Evaluation of the University System and Research (ANVUR) in Italy. The index measures the "distance" between the research productivity of a given department and the median productivity in the same field at national level.

\section{Table 1}

\section{Empirical approach}

The variable of interest of this study is "being" or "not being" a student that takes more than three years to obtain a degree. It is clearly a binary response variable since it can be defined by 1 , if there is delayed graduation or by 0 , otherwise 
Given the characteristics of this variable, the present study proposes a probit model, as it is appropriate for binary variables and it allows to model the probability to finish the university programme in the nominal duration according to a set of explanatory variables that can be divided into three groups. In Probit model the goodness of fit, namely the Akaike Information Criterion (AIC), the Bayesian Information Criterion (BIC), and the percentage of correct prediction (PCP), is higher compared to Logit approach ${ }^{1}$. The first group includes the inherent characteristics of the student such as gender (Male $=1$ if the student is male; zero otherwise) and age (Age). Furthermore, five dummy variables represent students' (upper) secondary studies (Other institutes, Technical secondary institute, Professional secondary institute, Teacher training school, Lyceum). The final score of such secondary studies is also included, calculated on a 100 points scale (Diploma_mark). In the second group the variables considered are family and geographical factors such as place of origin (Residential=1 if he/she comes from a village/city which is placed more than $30 \mathrm{~km}$ from the university; zero otherwise ${ }^{2}$ ) and family's average income (Income). The third group includes environmental variables that could affect student performance. More precisely, it focuses on those variables that directly relate to the quality features of the departments such as number of teachers per student (Teacher_ps), quality of research (DipQR) and students' opinions about teaching and environmental quality (Study_load; Organization; Teacher_availability; Infr_quality). A positive result is expected for all these variables. Since a positive students' evaluation can be driven by "generous" marks, which in turn can prevent a delayed graduation (Taylor et al., 2007), endogeneity problems may occur. To avoid this, the indicators are analysed using their difference between 2008/2009 and 2011/2012, which represent the beginning and the end of the period under study respectively. Table 2 shows the descriptive statistics of the variables under study.

\footnotetext{
${ }^{1}$ Probit model provides the following values: $\mathrm{AIC}=1465.912, \mathrm{BIC}=1531.721$ and $\mathrm{PCP}=0.661$. Logit model shows the following ones: $\mathrm{AIC}=1466.433, \mathrm{BIC}=1532.241$ and $\mathrm{PCP}=0.659$.

${ }^{2}$ The distance threshold has been set at 30 kilometres since it is the average radius of Sassari's commuter belt (Rete metropolitana di Sassari). Different thresholds are also tested but the main results still hold.
} 


\section{$\underline{\text { Table } 2}$}

\section{Results}

Students come mainly from high schools (more than 58\%) or technical secondary institutes (more than 24\%). Furthermore, $70.8 \%$ of them are residential students, which means that they come from a place further than $30 \mathrm{~km}$ from the University. In other words, this group of students cannot commute and need to find accommodation at the campus or the neighbouring structures. The dataset contains other relevant information, such as family income and final mark at secondary school. According to the data, $62.8 \%$ of students who enrolled in 2008 completed their degree in more than three years.

Table 3 and Table 4 report the marginal coefficients of the probit estimations. According to the first analysis (Table 3) the main factors that play a part in reducing the probability to be late in graduation are: final mark at secondary school, quality of departments' research, number of teachers per student and students' overall satisfaction. In particular, an increase of $1 \%$ in the final mark leads to a decrease of $0.0058 \%$ in the likelihood of not finishing the university programme within the nominal time (column 1). However, this variable suffers from a well-known endogenous problem. Following the famous example in Wooldridge (2010), the final mark at secondary school and the probability to end the undergraduate programme as soon as possible depend on an unobservable variable, namely ability. This issue has been taken into account when deciding to only include the growth rate of this variable from one year to the next among the controls set.

It has also been observed that departments features are relevant: the higher the environment 
quality of the department, the higher the likelihood that students exhibit a good performance. Students in departments with a higher quality research standard have a higher probability of finishing their studies within the nominal duration $(\operatorname{Dip} Q R=-0.25)$. A higher number of teachers per student also helps students to finish their studies in the expected time (Teacher $\_s=-0.037$ ). Finally, the overall satisfaction of students affects behaviour to the extent that a higher students' satisfaction is associated with a lower probability to end up studying for longer than the nominal time $($ Satisfaction $=-3.32)$.

Average income of families has a very small negative effect, but still significant at 0.10 level, on the variable of interest (Income $=-2.6 \mathrm{e}-07$ ). The place where students live shows the opposite effect and allows to confirm that those students who moved to Sassari to attend their chosen programme are more likely to end their studies in more than three years $($ Residential $=0.12)$.

Still focusing on table 3, a discussion of the interaction terms enables an analysis of the relationship between some of the variables under study. Looking at columns 2-4, one can see the interaction effect between the continuous variable age and the male dichotomy. It seems that male students have, on average, a lower rate of success (Male $=0.29$ ), although this effect decreases as their age increases $($ Age*Male $=-0.016)$. Furthermore, it is observed that male residential students are, on average, more likely to finish their studies in the given time than the female group $($ Male*Residential $=-0.13)$. Finally, no empirical evidence was found on the interaction between income and residential status. Therefore, the negative performance in terms of career duration among residential students is not due to low-income issues.

As anticipated in Section 2, this study considered the set of the sub-indicators that represent the subjective satisfaction of students in the following areas: Organization, Teaching and study activities, and Infrastructure. Table 4 provides the above-mentioned estimates.

All these sub-indicators, except Teacher_availability, do not exhibit any significant effect on students' performance, although all the coefficients have the expected sign. From these results it 
appears that the availability of teachers and TAs are relevant in explaining students' careers (Teacher_availability $=-5.99)$.

\section{$\underline{\text { Table } 3}$}

\section{$\underline{\text { Table } 4}$}

\section{Robustness check}

A concern that arises in the analysis of student performance is that some variables could not be exogenous. More precisely, the observed difference in careers between residential and commuter students may be driven by other variables rather than by their residential difference. This empirical issue is called sample selection bias. A convincing argument is given by Table 4, which shows the descriptive statistics of all the variables under study for the two groups: commuter and residential students. According to the pairwise t-tests (third column), the two groups are different in a number of variables, namely Income, Age, Male, secondary education (Lyceum, Teachers_institute, Other_institute) and department features (Department Research Quality DRQ, Students Satisfaction, Organization, Teacher_availability). A possible solution to this problem is provided by Propensity Score Matching, PSM (Rosenbaum and Rubin, 1983). When considering residential differences, the ideal analysis would consider a sample of observations, which are identical except for the observed characteristics. The difference in the outcomes of the "treated" sample and the "control" sample can then be correctly attributed to the variable under study.

The PSM technique is applied to obtain unbiased estimates of the residential effects on the students' careers. The matching technique is to select a control group of commuter students that are similar to the treated ones, i.e. residential students. In the first stage a probit regression is 
estimated on the data set using measurable variables of the characteristics of the students to predict the likelihood of being in the treated group. The estimated parameters are used to calculate the fitted probabilities of being a male. These fitted values are known as the propensity scores.

To do this, the teffects psmatch command (STATA13) has been employed. The estimated coefficient associated with the residential feature equals to $0.111(\mathrm{sd}=0.039$ and $\mathrm{p}$-value $=$ 0.004). As is evident from the results above, although the Residential coefficient is smaller than that obtained in the previous standard estimations, it is still statistical significant and its sign is consistent. These results are confirmed by graphical representation of the degree of overlap, which clearly show that problems of overlap do not appear in this dataset ${ }^{3}$.

Another way to deal with a sample selection bias is proposed by Blinder (1973) and Oaxaca (1973). The so-called Blinder-Oaxaca decomposition is a methodology used to study wages differences between groups (sex, race, etc.). This approach divides the observed output differential between the groups into two parts: the first one is "explained" by group differences in individual characteristics (e.g. education or age), while the second one represents the "unexplained" component, which accounts for both a measure for discrimination and the group differences in unobserved predictors.

\section{$\underline{\text { Table } 5}$}

The oaxaca command is performed in STATA13. Table 6 shows the results of the BlinderOaxaca decomposition. The mean share of delayed graduation is 0.547 for commuter students and 0.661 for residential students, yielding a statistically significant gap of -0.116 . This gap is divided into two components. The first part represents the mean increase in residential students' performance if they had the same characteristics as commuter ones, namely Income, Age, Male,

\footnotetext{
${ }^{3}$ The graphics are available upon request.
} 
Lyceum, Teachers_institute, Other_institute, DipQR, Satisfaction, Organization, Teacher_availability. However, such differences account for only a 0.0024 increase in students' performance. In fact, such a small number is not statistically significantly different from zero. So, the differences in endowments account for an insignificant part of the performance differential while a gap of -0.118 remains unexplained. This analysis confirms what we have found with the PSM technique: the difference in performance between the two groups remains even after controlling for potential selection bias.

\section{$\underline{\text { Table } 6}$}

\section{Discussion}

The present analysis documents the main factors in explaining the performance of undergraduate students, using the University of Sassari as a case study.

It emerges that students' satisfaction, both in terms of teaching and environmental features, has a positive influence on their performance (Marsh, 2007; Abrami et al., 2007; Theall and Feldman, 2007). This result is in line with the empirical literature (see, amongst others, Kemran and Lord, 1991; Hartman and Schmidt, 1995; Machado et al., 2011) that highlights the importance of student satisfaction in improving the efficacy of their performance at university and their future employability. As Taylor et al. (2007) and Waggoner and Goldman (2005) discussed, a winning strategy to improve student satisfaction and reputation is to encourage higher levels of success and graduation rates.

Student satisfaction assessment should also explore issues related to the status of residential and commuter students while, at the same time, collecting their suggestions to involve them more actively. 
The paper also gives some indication as to the individual and background factors that support the students' performance. These relevant factors were highlighted by Gitto el al (2016) and the previous literature on the topic cited in the framework of the paper.

Another important factor that needs to be considered is the distance between students' homes and universities (e.g., Gitto et al., 2016; Cingano and Cipollone, 2007; D’Hombres, 2007).

We find that residential students are more at risk of underperformance than their commuter peers.

According to Gitto et al (2016) residential students are more likely to enrol at University without taking into consideration self-motivation and commitment, and personal academic skills, probably in relation to the low expenses that they anticipate having to bear, compared to their commuter peers.

It is important to consider that universities fees do not represent an obstacle for residential students; in fact, tuition fees in Italy are generally lower than in other countries in Europe. Average tuition fees for a higher public education in Italy are between $€ 0-1.500 €$ per year. Academic fees are linked to student's family income and academic performance (Agasisti and Murtinu, 2016).

On the other hand, commuter students could be more conscious of the implication of being enrolled to the University, for example in relation to expenses and family pressures to complete their degrees.

Future researches should further investigate student's attitudes for these two types of students with the purpose of providing services focused on the different learning and vocational requirements.

There is no strong evidence of differences between commuter and residential students, 
particularly in European Universities. In addition, there is a small amount of research focusing on the differences between the academic performance of commuter and residential students, some of which contradicts the results of the present study.

In fact, several studies highlight (Jacoby, 2000; Newbold, 2011) the advantages and benefits for residential students. For example, they have easier access to university services and facilities, they are more involved with student community building and they can receive more support from the student network. Moreover, they do not spend time and effort travelling from their residence to University.

Other research, such as Gianoutsos and Rosser (2014), show that there are practically no differences in terms of academic performance among commuter and residential students. However, it should be considered that most of these studies are focused on the American University System, which is vastly different from the European system, and even more so in comparison to the Italian system. The culture of student campus life tyipical of Amercan universities is absent in Europe.

This should be translated into a higher effort by the institution to rectify this gap. This research highlights the need to calibrate the teaching provision in response to the various typologies of students, e.g. residential and commuter students, full-time and part-time students, students with and without disabilities. It is important to support all groups according to their needs, in order to facilitate and increase the sense of community among students, which will help them to improve their productivity and well-being (Bowles and Brindle, 2017).

This study emphasises the role played by Departments' research quality: the empirical evidence shows that high research productivity is positively correlated with the likelihood for students to finish in time. Moreover, the number of professors per students, taken here as a proxy of teaching supports, has a positive effect on the ability of students to finish their graduate studies within the given period. High teaching standard is positively correlated with student 
performance, as in Beltyukova and Fox (2002). A direct policy implication of these findings is that supporting academic staff and potentiating their performance in both research and teaching, has a positive effect on student performance. It would also be desirable to involve students in research projects in order to stimulate their active learning and skills development (Healey, 2005).

Finally, the higher productivity of commuter students compared to residential ones could be due to a sample selection bias. In other words, good students might prefer to complete their studies in institutions outside of Sardinia. This effect could be stronger among the incoming students since their opportunity cost is higher than it is for students from Sassari. This result is quite surprising since both the theory and the previous experimental investigations and surveys show a different relationship. A straightforward policy implication seems to be that the University of Sassari should promote new services in order to balance the situation between residential and commuter students and filling up such a gap.

Services should be made available and promoted to students by trying to finalise some specifics for commuter students to engage in university community building. Furthermore, it is important to annually monitor students' performance and satisfaction linked to a specific university service. This would enable a greater understanding as to which services are useful to prevent student drop-out (Bennet, 2003). At the same time, the implementation of activities supporting the professional identity of students during their degree could be recommended. Such activities would mitigate demotivation and student inactivity (Sweitzer, 2009).

A possible rationale for this controversial outcome is the fact that the quality level of services provided by the University of Sassari is not sufficient to give the same opportunity to the two groups. Students who move to live on the campus or nearby might have high costs in terms of adaptation to their new environment. This may have had some influence on their productivity. In this sense, it is important to increase funding in order to support student performance (Jacoby, 
2000). Another reason could be the presence of a sample bias. Students with better results at school prefer to complete their studies outside of Sardinia. This is even more true for students coming from outside of Sassari, since the difference between the expenditures associated with the two options, i.e. stay in Sardinia or move to another university in the North of Italy or abroad, is lower.

Students' ability to complete the degree programme within the nominal duration is an important issue in Italy since it is used by MIUR as a proxy of teaching performance. Therefore, students' behaviours impact on university system transfers. In this framework, the findings of this study can be a tool for university policies aimed at helping and supporting students during their careers. These findings will enable the promotion and elaboration of new strategies that satisfy student expectations and encourage a supportive and collaborative relationship between teachers, administration and students (OECD, 2002) (Bussu et al., 2018). However, this analysis should be replicated in other Italian universities in order to depict a clearer picture of the whole Italian system.

In alignment with Burgalassi et al. (2017), it is the authors' belief that Italian universities should strengthen services and facilities to support the degree choices of students and should consolidate their collaboration with high schools. In addition, Universities should promote ongoing guidance activities to support student self-management and self-determination (Lizzio and Wilson, 2005), and should implement new projects and training to develop student life skills, such as decisionmaking and problem-solving, aimed at increasing confidence in the management of daily life problems. Finally, it may be useful to rethink services and projects based on students' statuses (residential versus commuter or full-time versus part-time) and training needs. 


\section{Conclusions and implications}

This paper contributes to the international ongoing discussion on the development and implementation of teaching methods to support student performance. Notably, both students and university will benefit from these practices. Determining the main factors of student careers (in terms of duration, performance or drop-out) can help to identify new strategies and to design appropriate actions that support the student community. For all these reasons, this paper is not only of interest for the academic community, but it could also be useful for policy makers to identify strategies and incentives to improve student well-being and performance.

In view of the results emerged, it is the authors' belief that future research should be focused on student's attitudes and study propensities, particularly for two types of groups: residential and commuter students. Moreover, secondary education and higher education institutions should consider motivational and psychological support services focused on personal needs of different types of students.

Furthermore, in consideration of the direct relationship between research quality and performance students (i.e. to complete their degree in time), it is deemed crucial that lecturers have adequate time to implement research quality that they can transmit to their students. Lecturers over first year students enrolled is inversely and significantly correlated to dropouts (Gitto et a., 2016). For this reason, National government should increase permanent staff academic recruitment.

In conclusion, this research could be extended in order to analyse the moment in time where it is more frequent for students to fail in their university careers. For instance, Dekker et al. (2014) highlights that a higher drop-out rate is observed during the first year of study. One reason can be that students do not adapt to the new university environment. Alternatively, it could be a simple problem of matching between students and institutions: working with a limited set of information, students have a higher likelihood to commit a mistake during their first year than in 
subsequent years. Thus, in future analysis it could be very useful to analyse this issue in order to devise some strategies for motivating and involving students in the university context (Leveson et al., 2013). 


\section{References}

Abrami, P. C., D'Apollonia, S. and Rosenfield, S. (2007). "The dimensionality of student ratings of instruction: What we know and what we do not", in Perry R. P. and Smart J. C. (Eds.), The scholarship of teaching and learning in higher education: An evidence based perspective, Springer, Dordrecht, pp. 385-445.

Agasisti T. and Murtinu S.(2016). Grants in Italian university: a look at the heterogeneity of their impact on students' performances, Studies in Higher Education, Vol 41 No. 6, pp. 11061132.

Aikens, N. L. and Barbarin, O. (2008), Socioeconomic Differences in Reading Trajectories: The Contribution of Family, Neighbourhood, and School Contexts, Journal of Educational Psychology, Vol. 100 No. 2, pp. 235-251.

Alfano, H. L. and Eduljee, N. B. (2007), Differences in work, levels of involvement, and academic performance between residential and commuter students. College Student Journal, Vol. 47 No. 2, pp. 334-342.

Alhija, F. N. and Fresko, B. (2009), Student evaluation of instruction: What can be learned from students' written comments? Studies in Educational Evaluation, Vol. 35 No. 1, pp. 37-44.

Beltyukova, S. A., and Fox, C. M. (2002),Student satisfaction as a measure of student development: Towards a universal metric, Journal of College Student Development, Vol. 43 No. 2, pp. 161-172.

Belloc, F. Maruotti A. and Petrella, L (2011), How individual characteristics affect university students drop-out: a semiparametric mixed-effects model for an Italian case study, Journal of Applied Statistics, Vol. 38 No. 10, pp. 2225-2239.

Belloc, F. Maruotti A. and Petrella, L (2010), University drop-out: an Italian experience. High Educ., Vol. 60, pp. 127-138.

Bennet, R. (2003), Determinants of Undergraduate Student Drop Out Rates in a University Business Studies Department, Journal of Further and Higher Education, Vol. 27, pp. 123-141.

Blinder, A. S. (1973), Wage discrimination: Reduced form and structural estimates, Journal of Human Resources, Vol. 8, pp. 436-455.

Bond, C. H. (2000), The development of students' experiences of learning in higher education. Unpublished Ph.D. thesis, Griffith University, Queensland.

Boero, G., Laureti, T., and Naylor, R. A. (2005), An econometric analysis of student withdrwal and progression in the post-reform Italian univerisities. CRENOS Working paper, no. 1048.

Bowles, T.V. and Brindle, K. A. (2017), Identifying facilitating factors and barriers to improving student retention rates in tertiary teaching courses: a systematic review, Higher Education Research and Development, Vol. 36 No. 5, pp. 903-919. 
Burgalassi M., Biasi, V. Capobianco, R. and Mopretti, G. (2017), Il fenomeno dell'abbandono universitario precoce. Uno studio di caso sui corsi di laurea del Dipartimento di Scienze della Formazione dell'Università "Roma Tre". Italian Journal of Educational Research, Vol. 17, pp. 105-126.

Bussu, A., Veloria, C. N. and Boyes-Watson, C. (2018), StudyCircle: Promoting a Restorative Student Community, Pedagogy and the Human Sciences, Vol. 6 No. 1, pp. 1-20. Retrieved from https://scholarworks.merrimack.edu/phs/vol6/iss1/6

Chickering, A.W. (1974), Commuting vs. residential students: Overcoming educational inequities of living off campus, Jossey-Bass, San Francisco.

Choi, B. K. and Rhee, B. S. (2014), The influences of student engagement, institutional mission, and cooperative learning climate on the generic competency development of Korean undergraduate students, Higher Education, Vol. 67 No. 1, pp. 1-18.

Cingano, F., \& Cipollone, P. (2007), University drop-out: The case of Italy. Temi di discussione, Banca D'Italia, No. 626, pp.1-33.

Coate, K., Barnet, R. and Williams, G. (2001), Relationships Between Teaching and Research in Higher Education in England, Higher Education Quarterly, Vol. 55 No. 2, pp. 158-174.

Costantini, P. and Vitale, M.P. (2010), "Analyzing Undergraduate Student Graduation Delay: A Longitudinal Perspective", in Attanasio, M. and Carpursi, V. (Eds), Statistical Methods for the Evaluation of University Systems. Part of the series Contributions to Statistics, Springer, Berlin, pp. 145-159.

Dekker, G.W., Pechenizkiy, M. and Vleeshouwers, J.M. (2014), Predicting Dropout Student: An Application of Data Mining Methods in an Online Education Program, European Journal of Open, Distance and E-Learning, Vol. 17 No. 1, pp. 118-133.

D'Hombres, B. (2007), The impact of university reforms on dropout rates and students'status: Evidence from Italy, JRC Scientific and Technical Report, No. 40507, 1-36.

Dion, D. P. (2005), The Lisbon Process: a European Odyssey, European Journal of Education, Vol. 40 No. 3, pp. 295-313.

Di Pietro, G. and Cutillo, A. (2008), Degree flexibility and university drop-out: The Italian experience, Econom. Educ.Rev, Vol. 27, pp. 546-555.

Dugan, J.P., Garland, J.L., Jacoby, B. and Gasiorski, A. (2008). Understanding commuter student self-efficacy for leadership. A within-group analysis. NASPA Journal, Vol. 45 No. 8, pp. 282-310.

European Commission (2009). Progress toward the Lisbon Objectives in Education and Training- Indicators and Benchmarks 2009, Brussels, European Commission.

European Commission (2010). Joint Report by the Economic Policy Committee (Quality of Public Finances) and the Directorate-General for Economic and Financial Affairs of European Commission, European Economy Occasional Papers, Brussels, European Commission. 
Eurostat (2014), Share of young adults having completed tertiary education up to $37 \%$. Luxembourg, Office of the European Union, Luxembourg.

Eurydice (2010), Focus on Higher Education in Europe 2010: the impact of the Bologna Process. Resource document. Education, Audiovisual and Culture Executive Agency (EACEA P9 Eurydice), retrieved from http://www.eurydice.org.

Ghignoni, E. (2017), Family background and university dropouts during the crisis: the case of Italy, Higher Education, Vol. 73 No. 1, pp. 127-151.

Gibbs, G. (1995), The Relationship Between Quality in Research and Quality in Teaching, Quality in Higher Education, Vol. 1 No. 2, pp. 147-157.

Gitto L., Minervini L. F. and Monaco L.(2016), University dropouts in Italy: Are supply side characteristics part of the problem, Economic Analysis and Policy, Vol. 49, pp. 108-116.

Gianoutsos, D. and Rosser, V., (2014), Is there still a considerable difference? Comparing residential and commuter student profile characteristics at a public, research, commuter university, College Student Journal, Vol. 48 No. 4, pp. 613 -628.

Gianoutsos, D. (2011), Comparing the student profile characteristics between traditional residential and commuter students at a public, research-intensive, urban community university. Doctoral dissertation, University of Nevada-Las Vegas, retrieved from: http://digitalscholarship.unlv.edu/thesesdissertations/925

Grilli L., Rampichini C. and Varriale R. (2016), Statistical modelling of gained university credits to evaluate the role of pre-enrolment assessment tests: An approach based on quantile regression for counts, Statistical Modelling, Vol. 16 No. 1, pp. 47-66.

Hattie, J. and Marsh H. W. (1996), The Relationship Between Research and Teaching: A MetaAnalysis, Review of Educational Research, Vol. 66 No. 4, pp. 507-42.

Hanushek, E.A. and Rivkin, S.G. (2006), "Teacher Quality", in Hanushek E.A. and Welch F. (Eds.), Handbook of the Economics of Education, Elsevier, Amsterdam, North-Holland, pp.1-29

Hartman, D.E. and Schmidt, S. L. (1995), Understanding student/alumni satisfaction from a consumer's perspectives: the effects of institutional performance and program outcomes, Research in Higher Education, Vol. 36 No. 2, pp. 197-217.

Healey, M. (2005),Linking Research and Teaching to Benefit Student Learning, Journal of Geography in Higher Education, Vol. 29 No. 2, pp. 183-201.

Healey, M. and Roberts, J. (Eds) (2004), Engaging Student in Active Learning: Case Studies in Geography, Environment and Related Disciplines (Cheltenham: Geography Discipline Network and School of Environment, University of Gloucestershire), retrieved from: http://www2.glos.ac.uk/gdn/active/student.htm. 
Heublein, U. (2014), Students drop-out from German Higher Education Institutions. European Journal of Education, Vol. 49, No. 4, pp. 498-513.

Hodges, L. C. and Stanton, K. (2007), Translating comments on student evaluations into the language of learning. Innovative Higher Education, Vol. 31 No. 5, pp. 279-286.

Horn, L.J. and Berktold, J. (1998), Profile of undergraduates in U.S. postsecondary education institutions: 1995-96. Office of Educational Research and Improvement, U.S. Department of Education, Washington, DC.

Jacoby, B. (2000), Why Involve Commuter Students in Learning? New Directions for Higher Education, Vol. 2000 No.109, pp 3-12.

Jung, J. and Kim, Y. (2017), Exploring regional and institutional factors of international students' dropout: The South Korea case, Higher Education Quarterly, Vol. 72 No. 2, pp. 1-19.

Johnes, G. and McNabb, R. (2004), Never Give up on the Good Times: Student Attrition in the UK. Oxford Bulletin of Economics and Statistics, Vol. 66 No. 1, pp. 23-47.

Kemran, M. (2016), Why students drop out of the Bachelor of Arts. Higher Education Research and Development, Vol. 35 No. 5, pp. 983-996.

Kernan, M.C. and Lord, R. G. (1991), An Application of Control Theory to Understanding the Relationship Between Performance and Satisfaction, Human Performance, Vol. 4 No.3, pp. 173185.

Kuh, G.D., Gonyea, R.M. and Palmer, M. (2011), The Disengaged Commuter Student: Fact or Fiction? Commuter Perspectives, Vol. 27 No. 1, pp. 2-5.

Lee, R. (2004), Research and teaching: making - or breaking - the links, Planet, Vol. 12 No. 4 , pp. $9-10$

Leveson, L., McNeil, N. and Joiner, T. (2013), Persist or withdraw: The importance of external factors in students' departure intentions, Higher Education Research and Development, Vol. 32 No. 6, pp. 932-945.

Lewis, K. G. (2001), Making sense of student written comments, New Directions for Teaching and Learning, Vol. 2001 No. 87, pp. 25-32.

Lizzio, A. and Wilson, K. (2005), Self-managed learning groups in higher education: Students' perceptions of process and outcomes, Br J Educ Psychol., Vol 73 No. 3, pp. 373-390.

Machado, M., Brites, R. , Magalhães, A. and Sá, M. J.(2011), Satisfaction with Higher Education: critical data for student development, European Journal of Education, Vol 46 No. 3 , pp. 415- 432 .

Malcolm, M. (2014), A Critical Evaluation of Recent Progress in Understanding the Role of the Research-Teaching Link in Higher Education, Higher Education, Vol. 67 No. 3, pp. 289-301. 
Marsh, H. W. (2007), "Students' evaluations of university teaching: Dimensionality, reliability, validity, potential biases and usefulness", in Perry, R. P. and Smart J. C. (Eds.), The scholarship of teaching and learning in higher education, Springer, Dordrecht, pp. 319-383

Mega, C., Ronconi, L. and De Beni, R. (2014), What Makes a Good Student? How Emotions, Self-regulated Learning, and Motivation Contribute to Academic Achievement, Journal of Educational Psychology, Vol. 106 No. 1, pp. 121-31.

Newbold, J.J., Mehta, S.S. and Forbus, P. (2011), Commuter students: Involvement and identification with an institution of higher education, Academy of Educational Leadership Journal, Vol. 15 No. 2, pp. 141-153.

Noser, T.C., Manakyan H. and Tanner J. R. (1996), Research productivity and perceived teaching effectiveness: A Survey of Economics Faculty, Research in Higher Education, Vol. 37 No. 3, pp. 299-319.

Oaxaca, R. (1973), Male-female wage differentials in urban labor markets. International Economic Review, Vol. 14 No.3, pp. 693-709.

OECD, (2002), Responding to Student Expectations. OECD Publications Service, Paris, France.

Pocklington, T.C. and Tupper, A. (2002), No place to learn: Why universities aren't working, UBC press, Vancouver.

Quinn, J. (2013), Drop-out and Completion in Higher Education in Europe among Students from Under-represented Groups. NESET, Bruxelles.

Raponi V., Martella, F. and Maruotti, A. (2016), A biclustering approach to university performances: an Italian case study. Journal of Applied Statistics, Statistics in Education, Vol. 43 No.1, pp. 31-45.

Richardson, M. Abraham, C. and Bond, R. (2012), Psychological Correlates of University Students' Academic Performance: A Systematic Review and Meta-analysis, Psychological Bulletin, Vol. 138, No 2, pp. 353-87.

Robertson, J. and Bond C.H. (2001), Experiences of the Relation between Teaching and Research: What do academics value? Higher Education Research \& Development, Vol. 20 No.1, pp. 5-19.

Rosenbaum, P. R. and Rubin, D. B. (1983), The Central Role of the Propensity Score in Observational Studies for Causal Eects, Biometrika, Vol. 70 No.1, pp. 41-55.

Schnepf, S.V. (2015), University dropouts and labor market success, IZA World of Labor, Institute for the Study of Labor (IZA), Bonn, No. 182, pp.1-10, retrieved from http://dx.doi.org/10.15185/izawol.182

Scott, P. (2002), High wire, Education Guardian, p. 13. 
Snyder, T.D. and Dillow, S.A. (2011), Digest of Education Statistics 2010 (NCES 2011-015). U.S. Department of Education, National Center for Education Statistics. Washington, DC, Retrieved from http://nces.ed.gov/pubs2011/2011015.pdf.

Sweitzer, V. (2009), Towards a Theory of Doctoral Student Professional Identity Development: A Developmental Networks Approach, The Journal of Higher Education, Vol. 80 No. 1, pp. 133.

Taylor, J., Brites, R., Correia, F., Farhangmehr, M., Ferreira, B., Machado, M. L., Sarrico, C. and $\mathrm{Sa}^{\prime}$, M. J. (2007), Strategic enrolment management: improving student satisfaction and success in Portugal, Higher Education Management and Policy, Vol. 20 No. 1, pp.120-137.

Theall, M. and Feldman, K. A. (2007), Commentary and update on Feldman's (1997) identifying exemplary teachers and teaching: Evidence from student ratings, in Perry R. P. and Smart J. C. (Eds.), The scholarship of teaching and learning in higher education, Springer, Dordrecht, pp. $130-143$.

Thiele T., Singleton A., Pope, D. and Stanistreet, D. (2016), Predicting students' academic performance based on school and socio-demographic characteristics, Studies in Higher Education, Vol. 41 No. 8, pp. 1424-1446.

Triventi M. and Trivellato P. (2009), Participation, performance and inequality in Italian higher education in the 20th century, Higher Education, Vol. 57 No. 6, pp. 681-702.

Tucker, B. (2014),Student evaluation surveys: anonymous comments that offend or are unprofessional. Higher Education, Vol. 68 No. 3, pp. 347-358.

Waggoner, D. and Goldman, P. (2005), Universities as communities of fate. Institutional rhetoric and student retention policy, Journal of Education Administration, Vol. 43 No.1, pp. 86-101.

Weissberg, N.C., Owen, D.R., Jenkins, A.H. and Harburg, E. (2003), The incremental problem: Enhancing the predictability of academic success in an urban, commuter institution. Genetic, Social, and General Psychological Monographs, Vol. 129 No. 2, pp. 153-180.

Wooldridge, J. M. (2010), Econometric Analysis of Cross Section and Panel Data, The MIT Press, London, UK.

Young, P. (2006), Out of balance: lecturers' perceptions of differential status and rewards in relation to teaching and research, Teaching in Higher Education, Vol. 11 No. 2, pp. 191-202.

Zotti, R. (2015). Should I Stay Or Should I Go? Dropping Out From University: An Empirical Analysis Of Students' Performances. Working Papers 70, AlmaLaurea Inter-University Consortium.

Retrieved from http://www2.almalaurea.it/universita/pubblicazioni/wp/pdf/wp70.pdf. 
Table 1. Questionnaire design

\begin{tabular}{|c|c|c|}
\hline Area & Item & Indicator \\
\hline \multirow[b]{2}{*}{$\begin{array}{l}\text { 1) Organizational aspects of the } \\
\text { course }\end{array}$} & $\begin{array}{l}\text { (a) "The schedule of lectures, practice } \\
\text { and any other teaching activities has } \\
\text { been respected" }\end{array}$ & $\begin{array}{l}\text { Organization: represents how a given } \\
\text { department is able to organize } \\
\text { teaching and supporting activities. }\end{array}$ \\
\hline & $\begin{array}{l}\text { (b) "The workload required for this } \\
\text { course is appropriate in relation to the } \\
\text { number of credits allocated to it." }\end{array}$ & $\begin{array}{l}\text { Study load: measures the } \\
\text { relationship between the efforts } \\
\text { required to pass the exam } \\
\text { successfully and the number of } \\
\text { credits associated with the course. }\end{array}$ \\
\hline 2) Teaching and stud & $\begin{array}{l}\text { "The teacher and the teaching assistants } \\
\text { are available to answer any questions, } \\
\text { address any issues, and provide } \\
\text { teaching support." }\end{array}$ & $\begin{array}{l}\text { Teacher availability: represents a } \\
\text { proxy of teachers and TAs efforts in } \\
\text { supporting and helping students. }\end{array}$ \\
\hline 3) Infrastructure & $\begin{array}{l}\text { "The infrastructures (classrooms, } \\
\text { libraries, public areas, meeting rooms } \\
\text { etc.) are adequate." }\end{array}$ & $\begin{array}{l}\text { Infrastructure: indicates the quality } \\
\text { of the infrastructure provided by the } \\
\text { department }\end{array}$ \\
\hline 4) Overall assessment & $\begin{array}{l}\text { "On the whole I am satisfied about the } \\
\text { way the course has been carried out." }\end{array}$ & $\begin{array}{l}\text { Satisfaction: represents the overall } \\
\text { students' satisfaction about services, } \\
\text { infrastructures and teaching } \\
\text { quality/availability provided by the } \\
\text { department. }\end{array}$ \\
\hline
\end{tabular}


Table 2. Descriptive statistics (obs. $=1,167)$

\begin{tabular}{lccc} 
VARIABLES & Mean & Median & Std. Dev. \\
\hline Irregular_career & 0.628 & 1.00 & 0.483 \\
Income & $32,556.14$ & 17815.08 & $94,948.65$ \\
Age & 21.160 & 19.00 & 5.130 \\
Male & 0.303 & 0.00 & 0.460 \\
Residential & 0.708 & 1.00 & 0.454 \\
Diploma_mark & 78.891 & 78.00 & 12.178 \\
Lyceum & 0.581 & 1.00 & 0.493 \\
Technical_institute & 0.243 & 0.00 & 0.429 \\
Professional_institute & 0.049 & 0.00 & 0.236 \\
Teachers_institute & 0.091 & 0.00 & 0.288 \\
Other_institute & 0.036 & 0.00 & 0.188 \\
DipQR & -0.074 & -0.091 & 0.286 \\
Teacher_ps & 0.430 & 0.111 & 1.161 \\
Satisfaction & 0.015 & 0.012 & 0.024 \\
Organization & 0.005 & 0.014 & 0.058 \\
Study_load & 0.017 & 0.013 & 0.050 \\
Teacher_availability & 0.002 & 0.00 & 0.016 \\
Infrastructure & 0.007 & -0.011 & 0.083 \\
\hline
\end{tabular}


Table 3. Probit regression results (Dependent variable: irregular_career). Marginal coefficients

\begin{tabular}{|c|c|c|c|c|c|}
\hline VARIABLES & $\begin{array}{l}\text { Model } \\
\text { (1) }\end{array}$ & $\begin{array}{l}\text { Model } \\
\text { (2) }\end{array}$ & $\begin{array}{l}\text { Model } \\
\text { (3) }\end{array}$ & $\begin{array}{l}\text { Model } \\
\text { (4) }\end{array}$ & $\begin{array}{l}\text { Model } \\
(5)\end{array}$ \\
\hline Income & $\begin{array}{l}-2.6 \mathrm{e}-07^{*} \\
(1.3 \mathrm{e}-07)\end{array}$ & $\begin{array}{l}-2.7 \mathrm{e}-07 * \\
(1.4 \mathrm{e}-07)\end{array}$ & $\begin{array}{l}-2.4 \mathrm{e}-07^{*} \\
(1.4 \mathrm{e}-07)\end{array}$ & $\begin{array}{l}-2.5 \mathrm{e}-07^{*} \\
(1.4 \mathrm{e}-07)\end{array}$ & $\begin{array}{l}-5.0 \mathrm{e}-07^{*} \\
(2.9 \mathrm{e}-07)\end{array}$ \\
\hline Age & $\begin{array}{l}0.00039 \\
(0.0029)\end{array}$ & $\begin{array}{l}0.0077^{*} \\
(0.0041)\end{array}$ & $\begin{array}{l}0.00034 \\
(0.0029)\end{array}$ & $\begin{array}{l}0.0080 * \\
(0.0042)\end{array}$ & $\begin{array}{l}0.00048 \\
(0.0029)\end{array}$ \\
\hline Male & $\begin{array}{l}-0.029 \\
(0.033)\end{array}$ & $\begin{array}{c}0.29 * * * \\
(0.11)\end{array}$ & $\begin{array}{c}0.052 \\
(0.053)\end{array}$ & $\begin{array}{c}0.37 * * * \\
(0.10)\end{array}$ & $\begin{array}{l}-0.030 \\
(0.033)\end{array}$ \\
\hline Residential & $\begin{array}{c}0.12 * * * \\
(0.033)\end{array}$ & $\begin{array}{c}0.13 * * * \\
(0.033)\end{array}$ & $\begin{array}{c}0.17 * * * \\
(0.041)\end{array}$ & $\begin{array}{c}0.18^{* * * *} \\
(0.041)\end{array}$ & $\begin{array}{l}0.11 * * * \\
(0.036)\end{array}$ \\
\hline Diploma_mark & $\begin{array}{c}-0.0058 * * * \\
(0.0012)\end{array}$ & $\begin{array}{c}-0.0057 * * * \\
(0.0012)\end{array}$ & $\begin{array}{c}-0.0058 * * * \\
(0.0012)\end{array}$ & $\begin{array}{c}-0.0057 * * * \\
(0.0012)\end{array}$ & $\begin{array}{c}-0.0058 * * * \\
(0.0012)\end{array}$ \\
\hline DipQR & $\begin{array}{c}-0.25 * * * \\
(0.055)\end{array}$ & $\begin{array}{c}-0.25 * * * \\
(0.055)\end{array}$ & $\begin{array}{c}-0.25 * * * \\
(0.055)\end{array}$ & $\begin{array}{c}-0.25 * * * \\
(0.055)\end{array}$ & $\begin{array}{c}-0.25 * * * \\
(0.055)\end{array}$ \\
\hline Teacher_ps & $\begin{array}{c}-0.037 * * * \\
(0.012)\end{array}$ & $\begin{array}{c}-0.036^{* * *} \\
(0.012)\end{array}$ & $\begin{array}{c}-0.037 * * * \\
(0.012)\end{array}$ & $\begin{array}{c}-0.036^{* * *} \\
(0.012)\end{array}$ & $\begin{array}{c}-0.037 * * * \\
(0.012)\end{array}$ \\
\hline Satisfaction & $\begin{array}{c}-3.32 * * * \\
(0.63)\end{array}$ & $\begin{array}{c}-3.47 * * * \\
(0.63)\end{array}$ & $\begin{array}{c}-3.29 * * * \\
(0.63)\end{array}$ & $\begin{array}{c}-3.44 * * * \\
(0.64)\end{array}$ & $\begin{array}{c}-3.29 * * * \\
(0.63)\end{array}$ \\
\hline Technical_institute & $\begin{array}{c}0.076^{* *} \\
(0.035)\end{array}$ & $\begin{array}{c}0.073 * * \\
(0.035)\end{array}$ & $\begin{array}{c}0.077 * * \\
(0.035)\end{array}$ & $\begin{array}{c}0.074 * * \\
(0.035)\end{array}$ & $\begin{array}{c}0.076^{* * *} \\
(0.035)\end{array}$ \\
\hline Professional_institute & $\begin{array}{c}0.049 \\
(0.063)\end{array}$ & $\begin{array}{c}0.042 \\
(0.064)\end{array}$ & $\begin{array}{c}0.048 \\
(0.062)\end{array}$ & $\begin{array}{c}0.041 \\
(0.063)\end{array}$ & $\begin{array}{c}0.049 \\
(0.063)\end{array}$ \\
\hline Teachers_institute & $\begin{array}{l}0.085^{*} \\
(0.049)\end{array}$ & $\begin{array}{l}0.086^{*} \\
(0.049)\end{array}$ & $\begin{array}{c}0.082 \\
(0.050)\end{array}$ & $\begin{array}{l}0.082^{*} \\
(0.050)\end{array}$ & $\begin{array}{l}0.083^{*} \\
(0.050)\end{array}$ \\
\hline Other_institute & $\begin{array}{c}0.18 * * * \\
(0.064)\end{array}$ & $\begin{array}{c}0.17 * * * \\
(0.065)\end{array}$ & $\begin{array}{c}0.18 * * * \\
(0.064)\end{array}$ & $\begin{array}{c}0.18 * * * \\
(0.066)\end{array}$ & $\begin{array}{c}0.18 * * * \\
(0.064)\end{array}$ \\
\hline Age*male & & $\begin{array}{c}-0.016 * * * \\
(0.0062)\end{array}$ & & $\begin{array}{c}-0.017 * * * \\
(0.0061)\end{array}$ & \\
\hline Male*Residential & & & $\begin{array}{l}-0.13^{*} \\
(0.070)\end{array}$ & $\begin{array}{l}-0.14 * * \\
(0.070)\end{array}$ & \\
\hline Residential*Income & & & & & $\begin{array}{c}5.0 \mathrm{e}-07 \\
(4.5 \mathrm{e}-07)\end{array}$ \\
\hline $\begin{array}{l}\text { Observations } \\
\text { Loglikelihood }\end{array}$ & $\begin{array}{c}1,167 \\
-720.03\end{array}$ & $\begin{array}{c}1,167 \\
-716.45\end{array}$ & $\begin{array}{c}1,167 \\
-718.23\end{array}$ & $\begin{array}{c}1,167 \\
-714.67\end{array}$ & $\begin{array}{c}1,167 \\
-717.92\end{array}$ \\
\hline
\end{tabular}

Robust standard errors are indicated in parentheses. $* * *, * *$, and * represent the significance levels of $0.01,0.05$, and 0.10 respectively. 
Table 4. Probit regression results (Dependent variable: irregular_career). Marginal coefficients

\begin{tabular}{lcccc}
\hline VARIABLES & $\begin{array}{c}\text { Model } \\
(1)\end{array}$ & $\begin{array}{c}\text { Model } \\
(2)\end{array}$ & $\begin{array}{c}\text { Model } \\
(3)\end{array}$ & $\begin{array}{c}\text { Model } \\
(4)\end{array}$ \\
\hline Organization & -0.00050 & & & \\
& $(0.29)$ & & & \\
Study_load & & -0.12 & & \\
& & $(0.32)$ & & $-5.99 * * *$ \\
Teacher_availability & & & $(0.93)$ & -0.15 \\
Infrastructure & & & $(0.18)$ \\
& & & & 1,167 \\
Observations & 1,167 & 1,167 & 1,167 & $1,164.04$ \\
Loglikelihood & -734.76 & -734.53 & -714.45 & -734.04 \\
\hline
\end{tabular}

Independent variables included: Income, Age, Male, Residential, Diploma_mark, DipQR, Teacher_ps, Satisfaction, Technical institute, Professional_institute, Teachers_institute, Other_institute. Robust standard errors are indicated in parentheses. $* * *, * *$, and $*$ represent the significance levels of $0.01,0.05$, and 0.10 respectively. 
Table 5. Descriptive statistics (obs. $=1,167)$

\begin{tabular}{lccc} 
VARIABLES & $\begin{array}{c}\text { (N. 341) Mean } \\
\text { (Residential=0) }\end{array}$ & $\begin{array}{c}\text { (N. 826) Mean } \\
\text { (Residential=1) }\end{array}$ & $\begin{array}{c}\text { Pairwise } \\
\text { t-test }\end{array}$ \\
\hline & & & \\
Irregular_career & 0.547 & 0.661 & $-3.68^{* * *}$ \\
Income & $46,478.27$ & $26,823.87$ & $3.23^{* * *}$ \\
Age & 21.884 & 20.931 & $2.86^{* * *}$ \\
Male & 0.408 & 0.262 & $4.99^{* * *}$ \\
Diploma_mark & 78.077 & 79.201 & -1.44 \\
Lyceum_ & 0.607 & 0.550 & $1.793^{*}$ \\
Technical_institute & 0.223 & 0.253 & -1.058 \\
Professional_institute & 0.063 & 0.057 & 0.402 \\
Teachers_institute & 0.046 & 0.109 & $-3.434^{* * *}$ \\
Other_institute & 0.058 & 0.028 & $2.403^{* *}$ \\
DipQR & -0.041 & -0.087 & $2.501^{* *}$ \\
Teacher_ps & 0.409 & 0.439 & -0.398 \\
Satisfaction & 0.011 & 0.016 & $-3.116^{* * *}$ \\
Organization & 0.010 & 0.003 & $1.923^{*}$ \\
Study_load & 0.020 & 0.016 & 1.220 \\
Teacher_availability & 0.001 & 0.003 & -1.798 \\
Infrastructure & 0.001 & 0.009 & -1.564 \\
\hline
\end{tabular}


Table 6. The Blinder-Oaxaca decomposition (obs. $=1,167)$

\begin{tabular}{lccc} 
& Coef. & Rob. St. Err. & $\mathrm{z}$ \\
\hline Differential & & & \\
Prediction I (Residential=0) & 0.547 & 0.027 & $20.25^{* * *}$ \\
Prediction II (Residential=1) & 0.661 & 0.016 & $40.22^{* * *}$ \\
Difference & -0.116 & 0.031 & $-3.64^{* * *}$ \\
\hline & & & \\
\hline Decomposition & & & 0.23 \\
Explained & 0.002 & 0.010 & $-3.73^{* * *}$ \\
Unexplained & -0.118 & 0.031 &
\end{tabular}

